\title{
GEOHYDROLOGY AND SIMULATED GROUND-WATER FLOW IN AN IRRIGATED AREA OF NORTHWESTERN INDIANA
}

By Leslie D. Arihood and Mark E. Basch

U.S. GEOLOGICAL SURVEY

Water-Resources Investigations Report 92-4046

Prepared in cooperation with the INDIANA DEPARTMENT OF NATURAL RESOURCES 


\section{U.S. DEPARTMENT OF THE INTERIOR BRUCE BABBITT, Secretary}

\section{U.S. GEOLOGICAL SURVEY}

Robert M. Hirsch, Acting Director

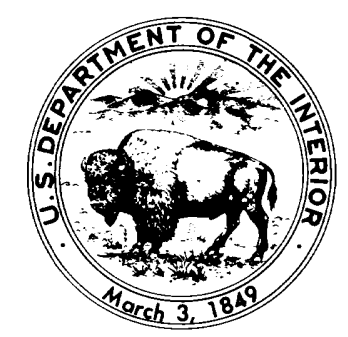

For additional information, write to:

District Chief

U.S. Geological Survey

Water Resources Division

5957 Lakeside Boulevard

Indianapolis, IN 46278-1996
Copies of this report can be purchased from:

U.S. Geological Survey

Earth Science Information Center

Open-File Reports Section

Box 25286, MS 517

Denver Federal Center

Denver, CO 80225 


\section{CONTENTS}

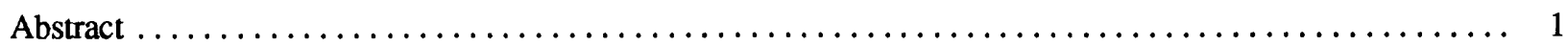

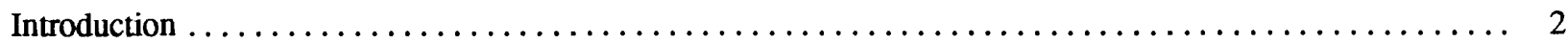

Purpose and Scope $\ldots \ldots \ldots \ldots \ldots \ldots \ldots \ldots \ldots \ldots \ldots \ldots \ldots \ldots \ldots \ldots \ldots \ldots \ldots \ldots \ldots \ldots \ldots \ldots \ldots \ldots \ldots \ldots \ldots, 2$

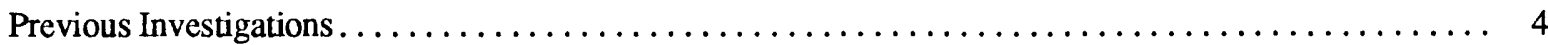

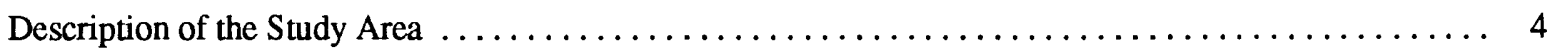

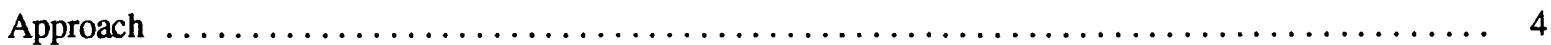

Acknowledgments $\ldots \ldots \ldots \ldots \ldots \ldots \ldots \ldots \ldots \ldots \ldots \ldots \ldots \ldots \ldots \ldots \ldots \ldots \ldots \ldots \ldots \ldots \ldots \ldots \ldots \ldots \ldots, \quad 5$

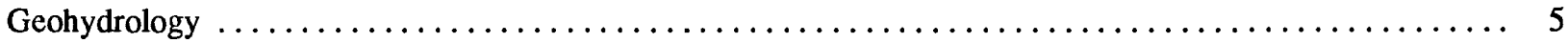

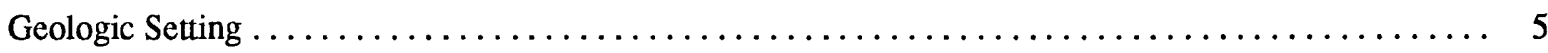

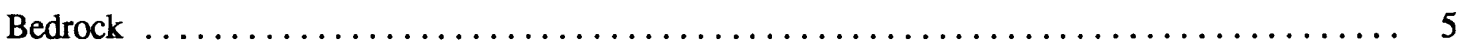

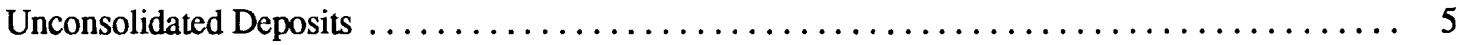

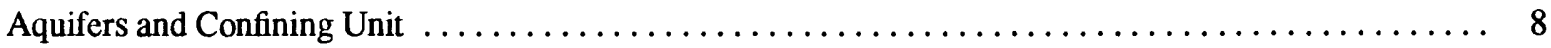

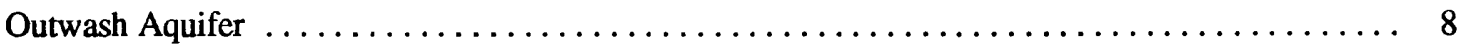

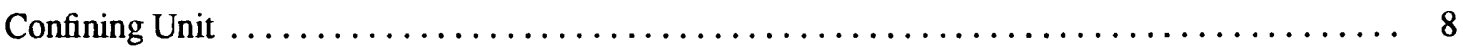

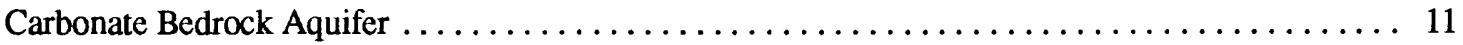

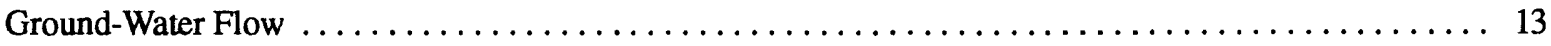

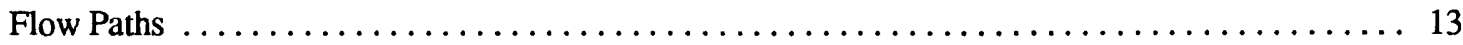

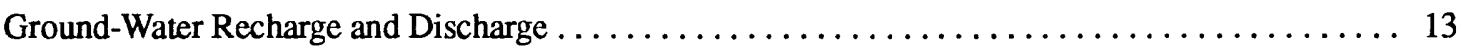

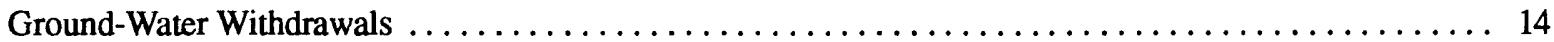

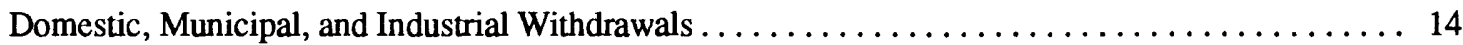

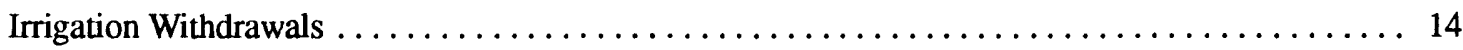

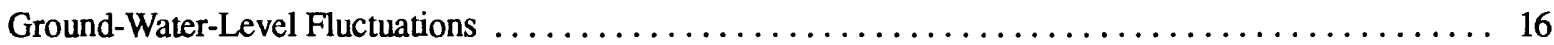

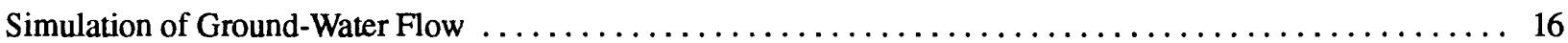

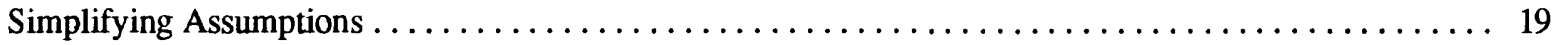

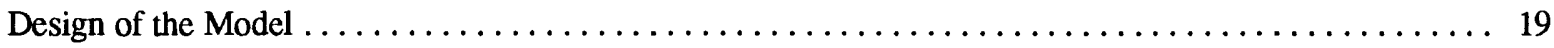

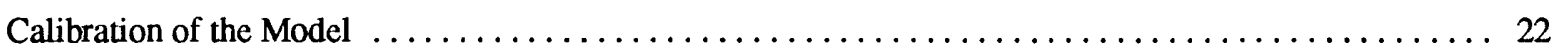

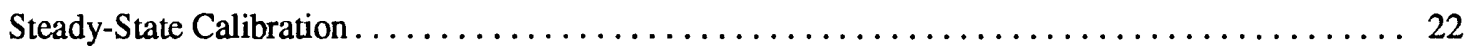

Transient Calibration to the Irrigation Season of $1986 \ldots \ldots \ldots \ldots \ldots \ldots \ldots \ldots \ldots \ldots \ldots \ldots \ldots$

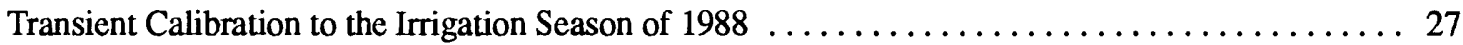

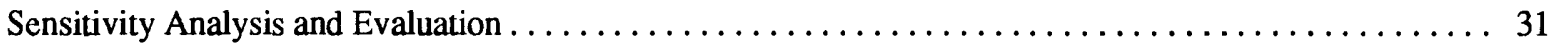

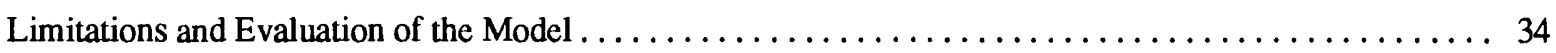

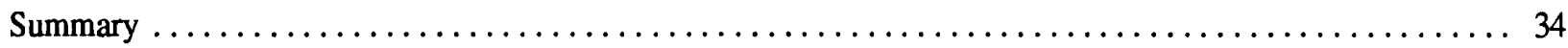

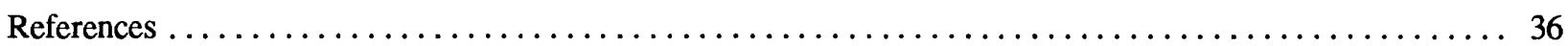

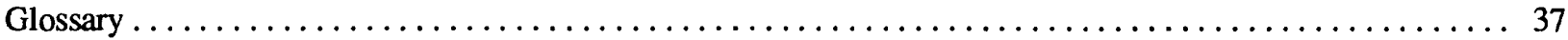




\section{FIGURES}

1-3. Maps showing:

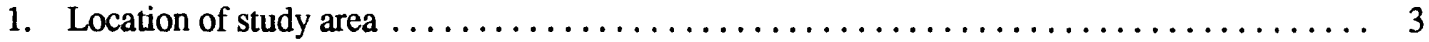

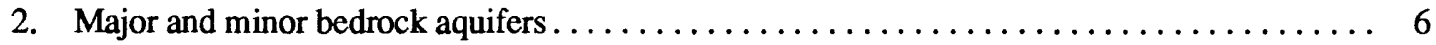

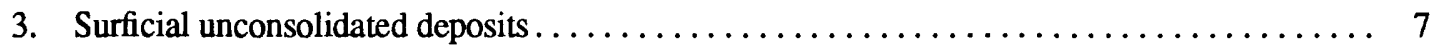

4. Generalized section showing major geohydrologic units and direction of ground-water flow ...... 9

5-8. Maps showing:

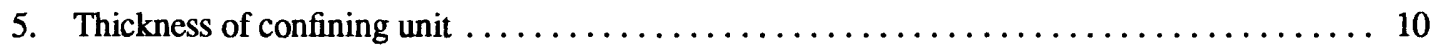

6. Regional transmissivity of the carbonate bedrock aquifer and of the shale.......... 12

7. Streamflow measurement sites, and the gains or losses between or upstream of sites ...... 15

8. Location of pumping centers of one or more wells pumping at least 100,000 gallons

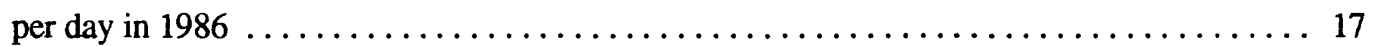

9. Hydrographs showing water-level fluctuations in selected observation wells $\ldots \ldots \ldots \ldots \ldots \ldots 18$

10. Model grid, types of model nodes, and model-boundary conditions $\ldots \ldots \ldots \ldots \ldots \ldots \ldots \ldots \ldots$

11. Generalized section showing model layers and boundary conditions used to represent

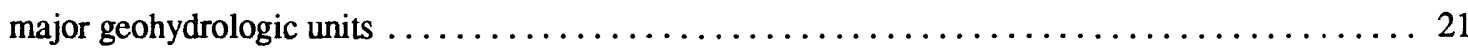

12-13. Hydrographs showing:

12. Simulated and measured water levels used for calibration of transient model,

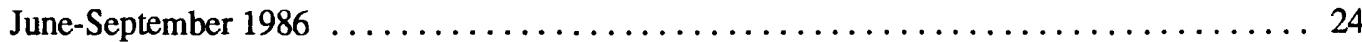

13. Simulated and measured water levels for the second calibration of the model,

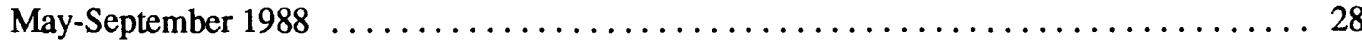

14. Map showing vertical hydraulic conductivity of the confining unit used for the second calibration of the model, May-September 1988

15. Hydrographs showing simulated and measured water levels used for resimulation of

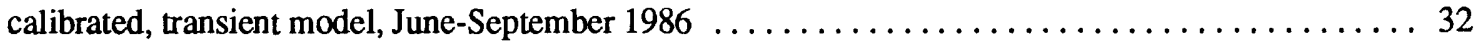

16. Map showing water-level contours in the carbonate bedrock aquifer, August $1986 \ldots \ldots \ldots \ldots . .33$

\section{TABLES}

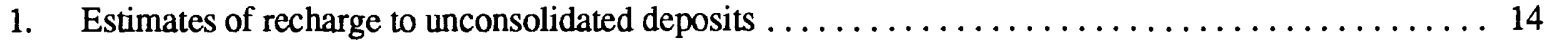

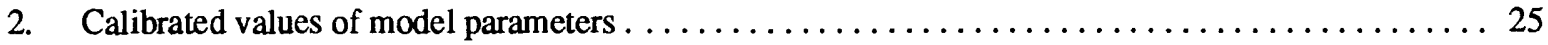

3. Water budget determined by transient calibration for June $1986 \ldots \ldots \ldots \ldots \ldots \ldots \ldots \ldots \ldots \ldots$

4. Water budget determined by transient calibration for August $1986 \ldots \ldots \ldots \ldots \ldots \ldots \ldots \ldots$

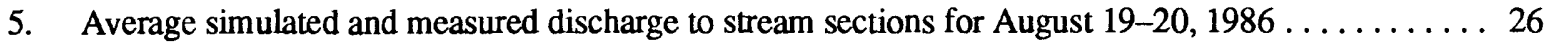

6. Water budget determined by the second calibration for June $1988 \ldots \ldots \ldots \ldots \ldots \ldots \ldots \ldots \ldots$

7. Water budget determined by the second calibration for August $1988 \ldots \ldots \ldots \ldots \ldots \ldots \ldots \ldots$

8. Results of changes in vertical hydraulic conductivity and transmissivity on the mean

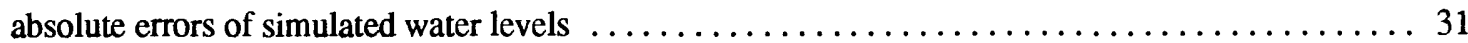




\section{CONVERSION FACTORS AND VERTICAL DATUM}

\begin{tabular}{rll}
\hline Multiply & By & To Obtain \\
inch (in.) & 25.4 & \\
foot (ft) & 0.3048 & millimeter \\
foot per day $(\mathrm{ft} / \mathrm{d})$ & 0.3048 & meter \\
foot squared per day $\left(\mathrm{ft}^{2} / \mathrm{d}\right)$ & 0.09290 & meter per day \\
cubic foot per second $\left(\mathrm{ft}^{3} / \mathrm{s}\right)$ & 0.02832 & meter squared per day \\
mile $(\mathrm{mi})$ & 1.609 & cubic meter per second \\
square mile $\left(\mathrm{mi}^{2}\right)$ & 2.590 & kilometer \\
gallon per minute $\left(\mathrm{gal} / \mathrm{min}^{2}\right)$ & 0.06309 & square kilometer \\
gallon per day (gal/d) & 0.003785 & liter per second \\
million gallons per day (Mgal/d) & 0.04381 & cubic meter per day \\
inch per year (in/yr) & 25.4 & cubic meter per second \\
foot per year $(\mathrm{ft} / \mathrm{yr})$ & 0.3048 & millimeter per year \\
& & meter per year \\
\hline
\end{tabular}

Temperature in degrees Celsius $\left({ }^{\circ} \mathrm{C}\right)$ can be converted to degrees Fahrenheit $\left({ }^{\circ} \mathrm{F}\right)$ as follows:

$$
{ }^{\circ} \mathrm{F}=\left(1.8^{\circ} \mathrm{C}\right)+32
$$

Sea level: In this report, "sea level" refers to the National Geodetic Vertical Datum of 1929 (NGVD of 1929)—a geodetic datum derived from a general adjustment of the first-order level nets of the United States and Canada, formerly called Sea Level Datum of 1929. 


\title{
Geohydrology and Simulated Ground-Water Flow in an Irrigated Area of Northwestern Indiana
}

\author{
by Leslie D. Arihood and Mark E. Basch ${ }^{1}$
}

\section{ABSTRACT}

Irrigation has been practiced since the early 1950's in parts of Newton and Jasper Counties and adjacent areas of northwestern Indiana. Ground-water is pumped for irrigation to supplement inadequate soil moisture during the growing season. Most of the water is pumped from the carbonate bedrock aquifer that underlies glacial drift. A concern related to pumping has been the lowering of water levels in the carbonate bedrock aquifer until the aquifer becomes dewatered-resulting in the depletion of the ground-water resource. As part of managing the ground-water resource, the Indiana Department of Natural Resources has supported the development and testing of a three-dimensional computer model of the ground-water-flow system.

Two major aquifers and a confining unit comprise the ground-water-flow system. The surficial, unconfined outwash aquifer consists of fine to coarse sand and some fine to medium gravel. The saturated thickness averages about 30 feet. Estimated values of horizontal hydraulic conductivity and storage coefficient are 350 feet per day and 0.07 , respectively.

\footnotetext{
${ }^{1}$ Indiana Department of Natural Resources, Indianapolis, Ind.
}

Estimated recharge to the outwash aquifer ranges from 12 to 14 inches per year. The generally continuous confining unit beneath the outwash aquifer is composed predominantly of till and lacustrine silt and clay and ranges in thickness from 0 to 125 feet. The vertical hydraulic conductivity of the confining unit is estimated to be $1.8 \times 10^{-4}$ to $1.8 \times 10^{-6}$ feet per day. The carbonate bedrock aquifer underlies the confining unit and is composed predominantly of Silurian and Devonian dolomitic limestone and dolomite. Irrigation wells usually derive water from this aquifer. Wells completed in the bedrock aquifer yield from 10 to 2,200 gallons per minute, mostly from secondary fractures and joints. Regional transmissivity for the bedrock aquifer ranges from 1,000 to 5,000 feet squared per day, and the median calculated transmissivity is about 2,000 feet squared per day.

A nine-layer digital model was developed to simulate flow in the ground-water system. The model used lithologic information and estimates of transmissivity and horizontal hydraulic conductivity from driller's logs, estimates of recharge from streamflow data, and historical pumpage data. The mean absolute errors for simulated water levels in the bedrock aquifer ranged from 5 to 7 feet for two periods of irrigation. The model is most accurate where data for confining-unit thickness and bedrock water levels are available. 
Model results indicate that most ground water is derived locally from precipitation recharge, which leaks to the bedrock aquifer rather than originating as flux across the study-area boundaries. The clay confining unit is the most important component of the flow system because it controls the rate of leakage to and affects the water-level drawdowns in the bedrock aquifer. Pumping does not significantly affect total flow in the system. Even in the dry year of 1988, when irrigation increased, pumpage in August was only 28 percent of total flow through the system. Although irrigation pumpage does not exceed recharge, drawdowns in the bedrock aquifer caused by pumpage can lead to conflicts among ground-water users.

\section{INTRODUCTION}

Irrigation has been practiced since the early 1950's in parts of Newton and Jasper Counties and adjacent areas of northwestern Indiana (fig. 1) to supplement inadequate soil moisture during the growing season. Most of the water for irrigation is pumped from a carbonate bedrock aquifer ${ }^{2}$ that underlies extensive glacial drift. Seasonal irrigation pumpage has caused large water-level declines in several observation wells in Newton and Jasper Counties (Basch and Funkhouser, 1985). Similar declines could occur in Lake and Porter Counties as irrigation demand increases. In Illinois, pumping from the same bedrock aquifer is causing ground-water-level declines and interstate water-resource concerns at the State boundary. In both states, pumping can lower water levels until the carbonate bedrock aquifer is dewatered and ground-water resources are depleted.

In 1976, the U.S. Geological Survey, in cooperation with the Indiana Department of Natural Resources, began a study to assess the effects of irrigation on the ground-water system in

\footnotetext{
${ }^{2}$ Terms in bold are defined in the Glossary, page 37.
}

Newton and Jasper Counties, Indiana (Bergeron, 1981). One of the objectives of the 1976 study was to evaluate the short-term and long-term effects of increasing pumping on ground-water levels and streamflow. A computer model that simulates ground-water flow was developed to help determine these effects.

In 1986, the U.S. Geological Survey, in cooperation with the Indiana Department of Natural Resources, began a new study that used recent pumpage data and water-level hydrographs to further refine hydraulic characteristics used in a new model described by this report. In the previous model by Bergeron (1981), data for large ground-water withdrawals for irrigation in several areas were not available for simulation and a more rigorous test of Bergeron's model was not possible. Irrigation withdrawals for 1986 used in the new model provided an opportunity to test the modelparameter values determined with Bergeron's model (1981). After testing, calibrated parameter values for the new model then were further evaluated by use of pumpages from a year of large withdrawals (1988). The two sets of pumpages stressed the model within the anticipated range of application by the Indiana Department of Natural Resources.

\section{Purpose and Scope}

The purpose of this report is to describe the geohydrologic setting, the effects of recent irrigation pumping on ground-water levels in parts of Newton and Jasper Counties and adjacent areas, and the results of computer simulations of the ground-water-flow system during two recent irrigation seasons. The description of the geohydrology includes general geology, aquifer geometry, hydraulic characteristics of the aquifers and confining unit, and the sources, discharges, and flow paths of ground water. The effects of recent pumping are illustrated by ground-water hydrographs of the sand and gravel aquifer and carbonate bedrock aquifer. The simulations used a finite-difference, three-dimensional, ground-water-flow model. Model development, calibration, sensitivity analysis, and limitations are described. Irrigation pumpage data from 1986 and 1988 were used to refine model parameters and to test model design. 


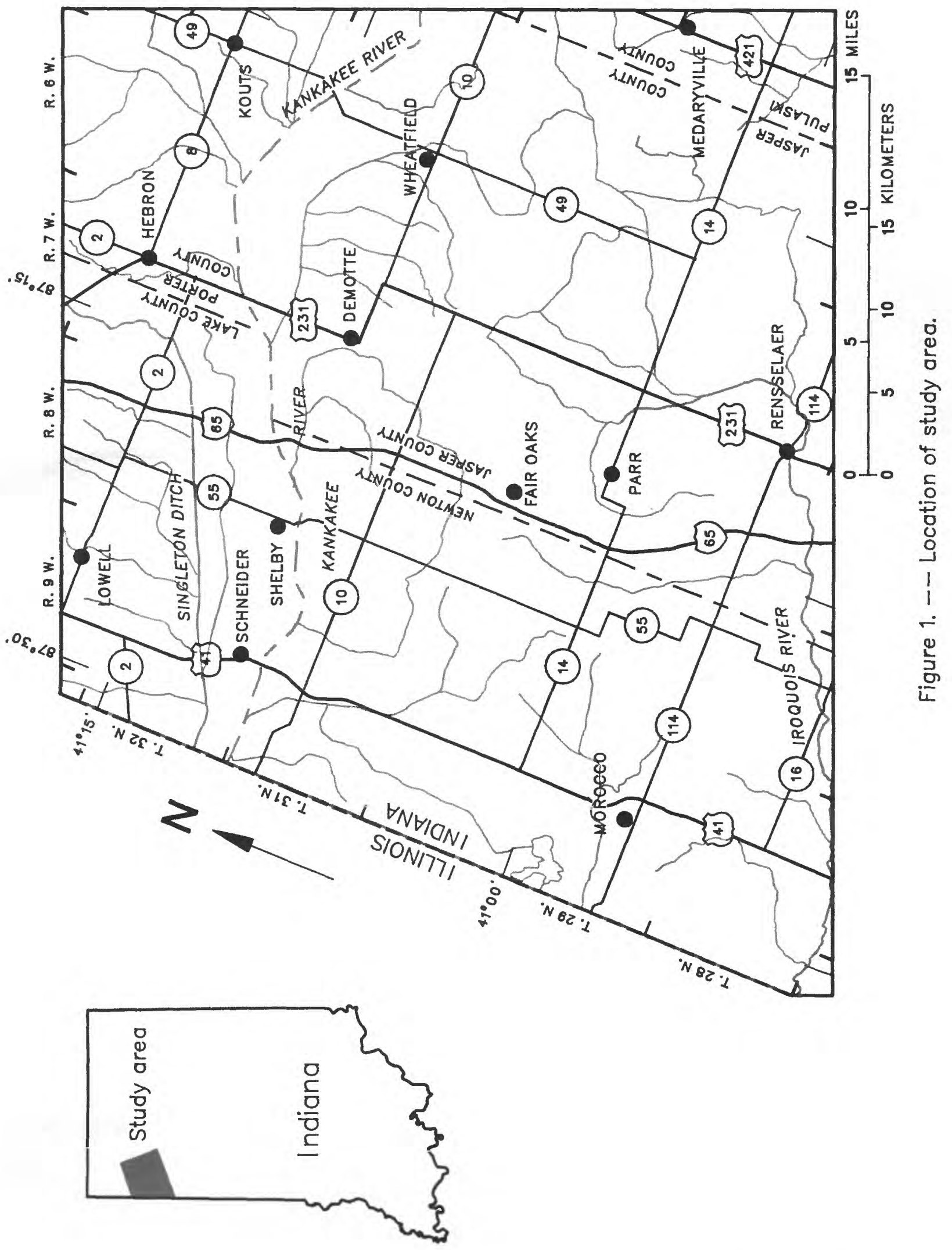




\section{Previous Investigations}

Several reports describe the general hydrology of the ground-water resources of Newton and Jasper Counties, and one report presents quantitative information on aquifer properties and yields. Preliminary investigations of the ground-water resources and the geology of Newton County (Rosenshein and Hunn, 1964b) and Jasper County (Rosenshein and Hunn, 1964a) provide general information on the geology and the major sources of ground water in addition to tabulated records of water-well and test-hole data. A report on the water and land resources of the Kankakee River basin, including Newton and Jasper Counties, presents information on general groundwater availability, ground-water flow, bedrock elevation, and the geometry and areal extent of the surficial unconfined outwash aquifer (State of Indiana and others, 1976). The effects of simulated irrigation pumpage on ground- and surface-water systems were assessed by Bergeron (1981) with a digital ground-water-flow model of an area similar to the area described in this report.

The general nature of statewide irrigation and the potential of future irrigation development in Indiana have been summarized in reports by Uhl and Kingsbury (1957); Kemp and others (1967); Kemp (1970); and the Governor's Water Resource Study Commission, State of Indiana (1980, p. 161, 479,482 , and 489). These studies describe the general aspects of irrigation throughout Indiana but provide little detailed information on current acreage irrigated with ground water in the study area. Basch and Funkhouser (1985) discuss the hydrogeology and the chemistry of ground waters in Newton and Jasper Counties and offer possible alternatives to help meet current ground-water demand.

\section{Description of the Study Area}

The $987-\mathrm{mi}^{2}$ study area includes parts of Newton and Jasper Counties and adjacent areas of northwestern Indiana (fig. 1). The area is within the Central Lowland physiographic province
(Schneider, 1966, p. 40). The topography is characteristic of the nearly flat landscape of the Kankakee Outwash and Lacustrine Plain of the Northern Lake and Moraine area of Indiana (Schneider, 1966, p. 52). The altitude of the land surface ranges from about $755 \mathrm{ft}$ three miles north of Hebron, in Porter County, to $620 \mathrm{ft}$ in places along the Kankakee River in northwestern Newton County. Prominent features of the landscape include numerous sand dunes and end moraines.

The study area is drained by a network of streams and ditches tributary to the Kankakee and Iroquois Rivers (fig.1). The Iroquois River is tributary to the Kankakee River about $15 \mathrm{mi}$ west of Newton County in Illinois.

The climate is temperate continental, with a mean annual temperature of $51.3^{\circ} \mathrm{F}$, based on 30 years of record (1951-80) at Kentland (National Oceanic and Atmospheric Administration, 1985, p. 8), which is $10 \mathrm{mi}$ south of Morocco. The mean monthly temperature ranges from $23.8^{\circ} \mathrm{F}$ in January to $74.6^{\circ} \mathrm{F}$ in July. The mean annual precipitation at Kentland is 37.4 in. (National Oceanic and Atmospheric Administration, 1985, p. 3), and the mean monthly precipitation ranges from 1.64 in. in February to 4.51 in. in July.

\section{Approach}

Geohydrologic data were collected to define the ground-water-flow system. Driller's logs from the Indiana Department of Natural Resources were used to map the areal extent and the thickness of the two major aquifers and confining unit. Ground-water levels were measured during the growing season of 1986 and 1988 in about 40 observation wells installed by the U.S. Geological Survey in cooperation with the Indiana Department of Natural Resources. The water-level data were used to determine seasonal fluctuations of water levels in the outwash and bedrock aquifers. Flow in selected stream sections was measured at about 40 sites during a low-flow period (August 19-20, 1986) to estimate ground-water discharge to the streams and recharge to the outwash 
aquifer. Historical monthly irrigation- and municipal-pumpage rates were obtained from files of the Indiana Department of Natural Resources for wells capable of pumping $0.1 \mathrm{Mgal} / \mathrm{d}$ or more.

A digital ground-water-flow model was constructed to test model-parameter values derived with Bergeron's model (1981). The model was calibrated using 1986 and 1988 data. The resulting parameter values then were compared to that used by Bergeron (1981).

\section{Acknowledgments}

The authors thank the Indiana Department of Natural Resources for geohydrologic and wateruse data that were used extensively in modeling activities. Robert Reynolds and Gregory Main of the Department of Natural Resources were particularly helpful in explaining irrigation practices, providing various data, and assisting in model development. We appreciate the contribution of ground-water-level data by Steven Wilson of the Illinois State Water Survey.

\section{GEOHYDROLOGY}

\section{Geologic Setting}

\section{Bedrock}

The study area is underlain by dolomitic limestone, dolomite, shale, sandstone, and minor amounts of siltstone ranging in age from Cambrian to Early Pennsylvanian. In general, Cambrian and Ordovician rocks lie at depths exceeding 1,300 and $650 \mathrm{ft}$, respectively. The major bedrock aquifer is composed of dolomitic limestone and dolomite of Middle Silurian and Devonian age that underlie the glacial drift in most of the study area (fig. 2).

Minor aquifers include Devonian shale and interbedded siltstone and Mississippian shale that underlie the drift in the southern part of Newton County and in northeastern Jasper County.

The Kankakee arch (fig. 2) is a major structural feature that strikes northwest to southeast. The bedrock dips southwest and northeast away from the arch. A map of the altitude of the upper surface of the bedrock (Bergeron, 1981, fig. 3) indicates that the altitude of the bedrock slopes northwest. The bedrock surface exhibits little relief except in an area along an ancestral bedrock valley, known as the Rensselaer buried valley, in southern Newton and Jasper Counties. The valley axis, which lies south of the study area, trends similarly to the Iroquois River. The Rensselaer buried valley cuts across and disrupts the continuity of the Kankakee arch north of Rensselaer. The valley does not extend significantly into the study area. Bergeron (1981, p. 6), however, indicates that: (1) the width of the buried valley generally ranges from 1 to $3 \mathrm{mi}$; (2) the valley roughly parallels the Iroquois River; (3) maximum relief along the valley is $110 \mathrm{ft}$; and (4) bedrock altitudes range from 493 to $603 \mathrm{ft}$ above sea level.

\section{Unconsolidated Deposits}

Glacial drift in the study area ranges in thickness from about 40 to $170 \mathrm{ft}$. The surficial deposits in the central part of the study area are composed predominantly of sand and gravel associated with the broad Kankakee outwash and lacustrine plain (fig. 3). Regionally, this outwash plain forms an extensive sand and gravel deposit that ranges in width from 15 to $25 \mathrm{mi}$ and extends from the northern boundary of Indiana to the Illinois State line. Within the study area, the deposit generally ranges in thickness from 5 to $60 \mathrm{ft}$.

At the northern boundary of the study area, the outwash is overlain by the Valparaiso end moraine (Schneider and Keller, 1970) and by ground moraine. The outwash thins to the south where it is bordered by the Iroquois end moraine (Wayne and others, 1966) and by ground moraine, which are composed predominantly of till and lacustrine silt and clay. The end and ground moraines also include windblown sand, lenses of sand and gravel, and ice-contact stratified drift. The morainal deposits extend beneath the outwash plain to the north and separate it from the underlying bedrock. In areas where these deposits are absent, the outwash sand and gravel directly overlie the bedrock surface. 


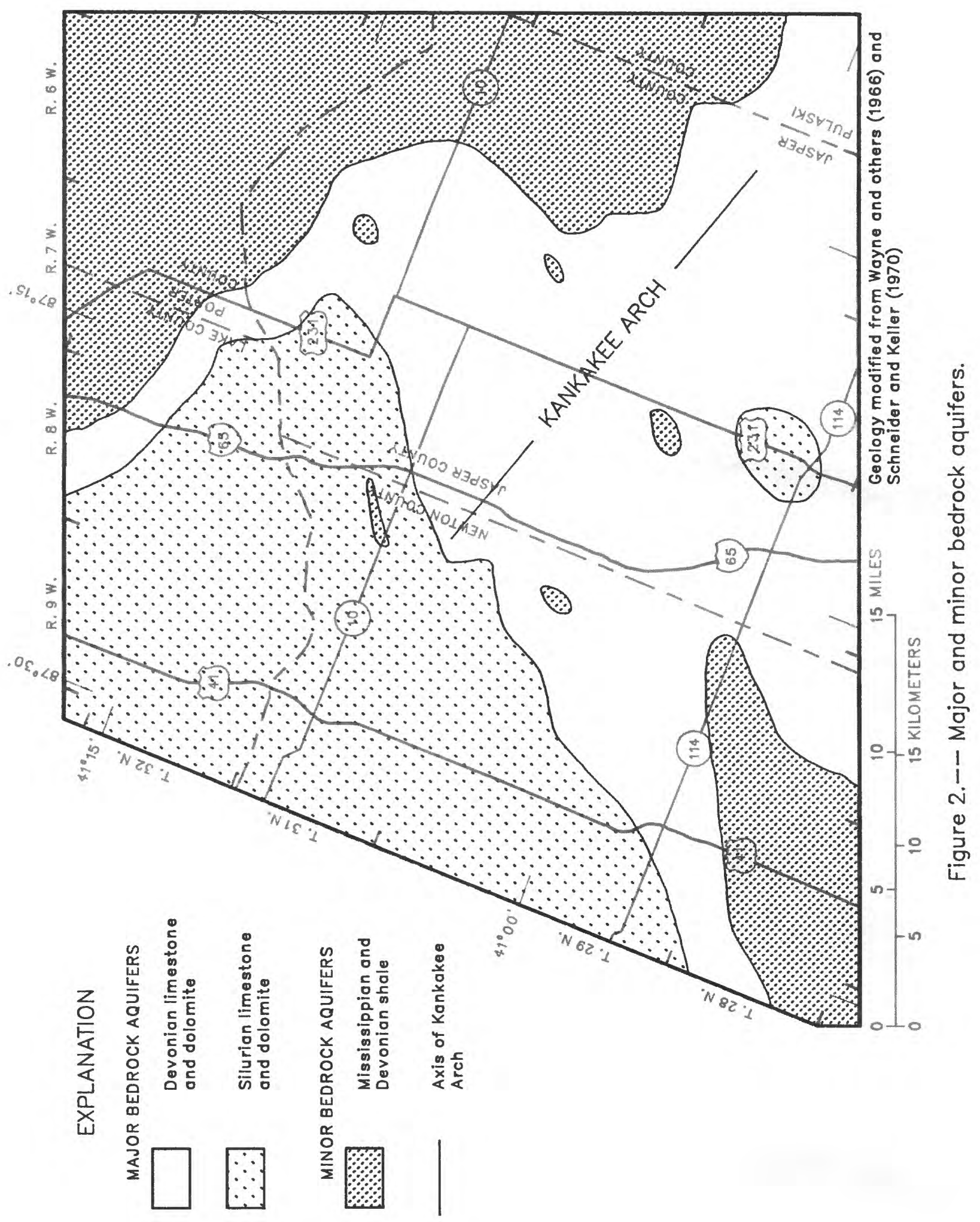




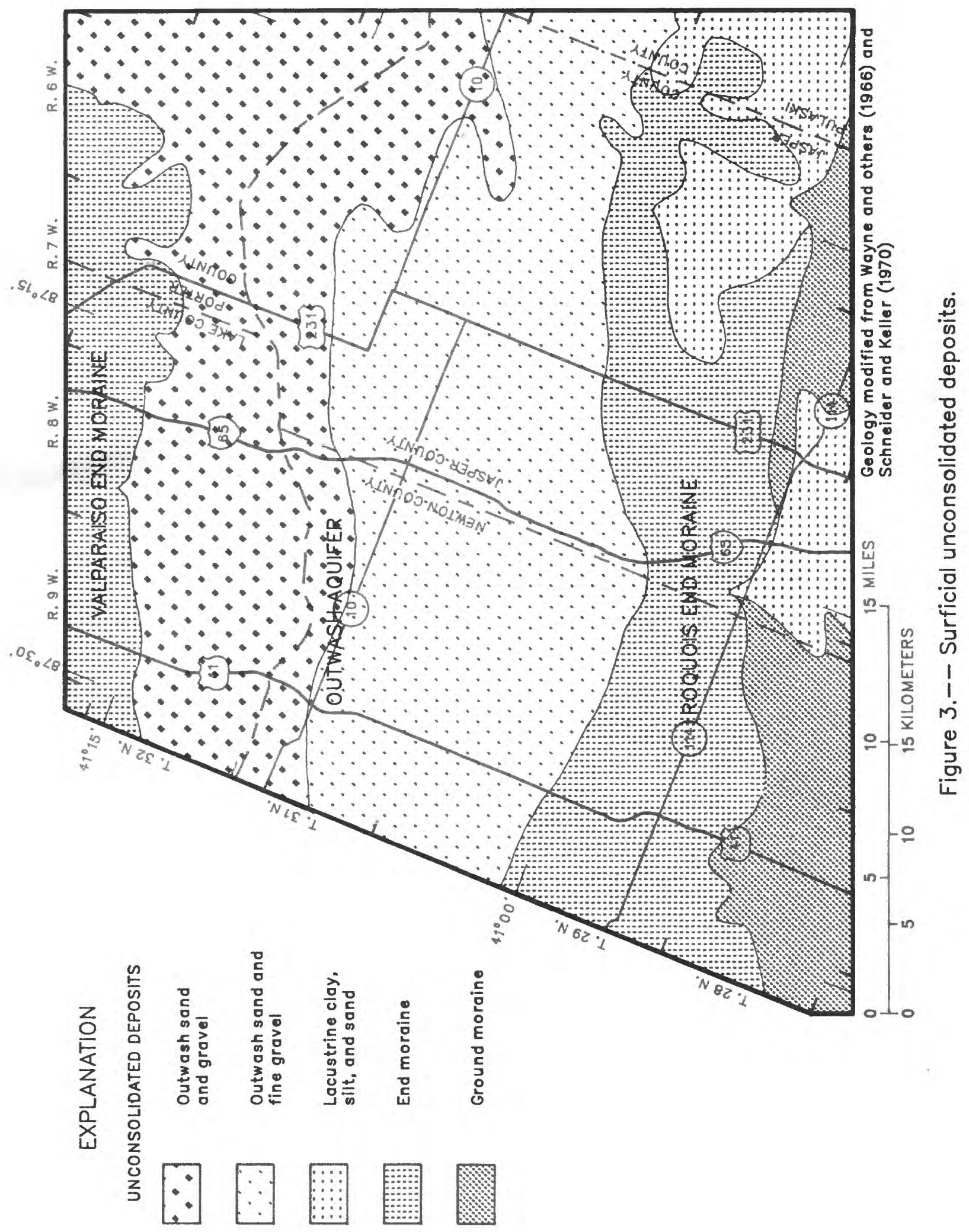




\section{Aquifers and Confining Unit}

Two major aquifers and a confining unit were identified in the study area from driller's logs. Surficial outwash deposits form the unconfined outwash aquifer, and Silurian and Devonian limestone and dolomite form a confined carbonate bedrock aquifer. A generally continuous confining unit, consisting predominantly of till and lacustrine silt and clay, separates the confined bedrock aquifer from the unconfined aquifer. A confined outwash aquifer lies at the southwestern boundary of the study area in the Rensselaer bedrock valley; however, the aquifer averages only $14 \mathrm{ft}$ in thickness and extends over only 4 percent of the study area near the southwestern boundary. Therefore, the confined outwash is not a significant aquifer in the study area. Also, the shale deposits in southwestern Newton County and northeastern Jasper County are classified as minor aquifers because of their low permeability. The vertical and lateral relations among the major aquifers and confining unit are shown by the generalized section in figure 4.

\section{Outwash Aquifer}

The unconfined outwash aquifer underlies an area of $465 \mathrm{mi}^{2}$ in north and central Newton and Jasper Counties and consists of medium to coarse sand and fine to medium gravel. The aquifer extent is defined by the outwash deposits shown in figure 3. The southern boundary of the outwash aquifer is the Iroquois end-moraine and groundmoraine deposits. In Lake and Porter Counties, the aquifer becomes confined where it is overlain by the Valparaiso end moraine and the associated till plain. The till extends from the end moraine by dipping beneath the Kankakee aquifer and separating it from the underlying bedrock aquifer (fig. 4). In a few areas of northern Jasper County, where the confining unit is absent, the Kankakee aquifer directly overlies the bedrock surface.

The outwash aquifer is the principal source of ground water for stock and domestic supplies and a major source of irrigation water in the northeastern part of the study area. The saturated thickness of the aquifer averages about $30 \mathrm{ft}$ and generally ranges from a few feet to $60 \mathrm{ft}$ (Bergeron, 1981, p. 11). Irrigation wells completed in the aquifer generally yield from 100 to $200 \mathrm{gal} / \mathrm{min}$.

The hydraulic conductivity of the outwash aquifer was estimated by Bergeron (1981, p.11) to be $250 \mathrm{ft} / \mathrm{d}$. Analysis of hydraulic conductivity for the entire aquifer during model calibration (see section titled "Transient Calibration to the Irrigation Season of 1986") indicated that horizontal hydraulic conductivity was $350 \mathrm{ft} / \mathrm{d}$. Using an average saturated thickness of $30 \mathrm{ft}$, the average transmissivity of the outwash aquifer was estimated to be $10,500\left[\left(\mathrm{ft}^{3} / \mathrm{d}\right) / \mathrm{ft}^{2}\right] \mathrm{ft}$ (hereafter reduced to $\mathrm{ft}^{2} / \mathrm{d}$ ). The specific yield of the outwash aquifer also was estimated during calibration (see section titled "Transient Calibration to the Irrigation Season of 1986"). The value that best simulated water-level declines and release of water from storage was 0.07 .

\section{Confining Unit}

Well-log information indicates that a generally continuous confining unit separates the outwash aquifer from the underlying carbonate bedrock aquifer (fig.4). The confining unit is composed predominantly of till and lacustrine silt and clay and includes end moraine, ground moraine, isolated lenses of sand and gravel, and ice-contact deposits. The confining unit generally ranges in thickness from 0 to $125 \mathrm{ft}$ (fig. 5) and is thickest throughout Newton County and central Jasper County, where thickness generally exceeds $35 \mathrm{ft}$. The confining unit thins to less than $10 \mathrm{ft}$ northeast of Fair Oaks and Demotte. In a few small areas where the unit is absent, the outwash aquifer directly overlies the bedrock surface. The vertical hydraulic conductivity of the confining unit probably is similar to that of a clay layer overlying the bedrock in Lake County, which Rosenshein and Hunn (1968, p. 21) estimated to be $4 \times 10^{-4} \mathrm{ft} / \mathrm{d}$. During model calibration (see section titled "Transient Calibration to the Irrigation Season of 1986"), the vertical hydraulic conductivity was estimated to range from $1.8 \times 10^{-4}$ to $1.8 \times 10^{-6} \mathrm{ft} / \mathrm{d}$. 

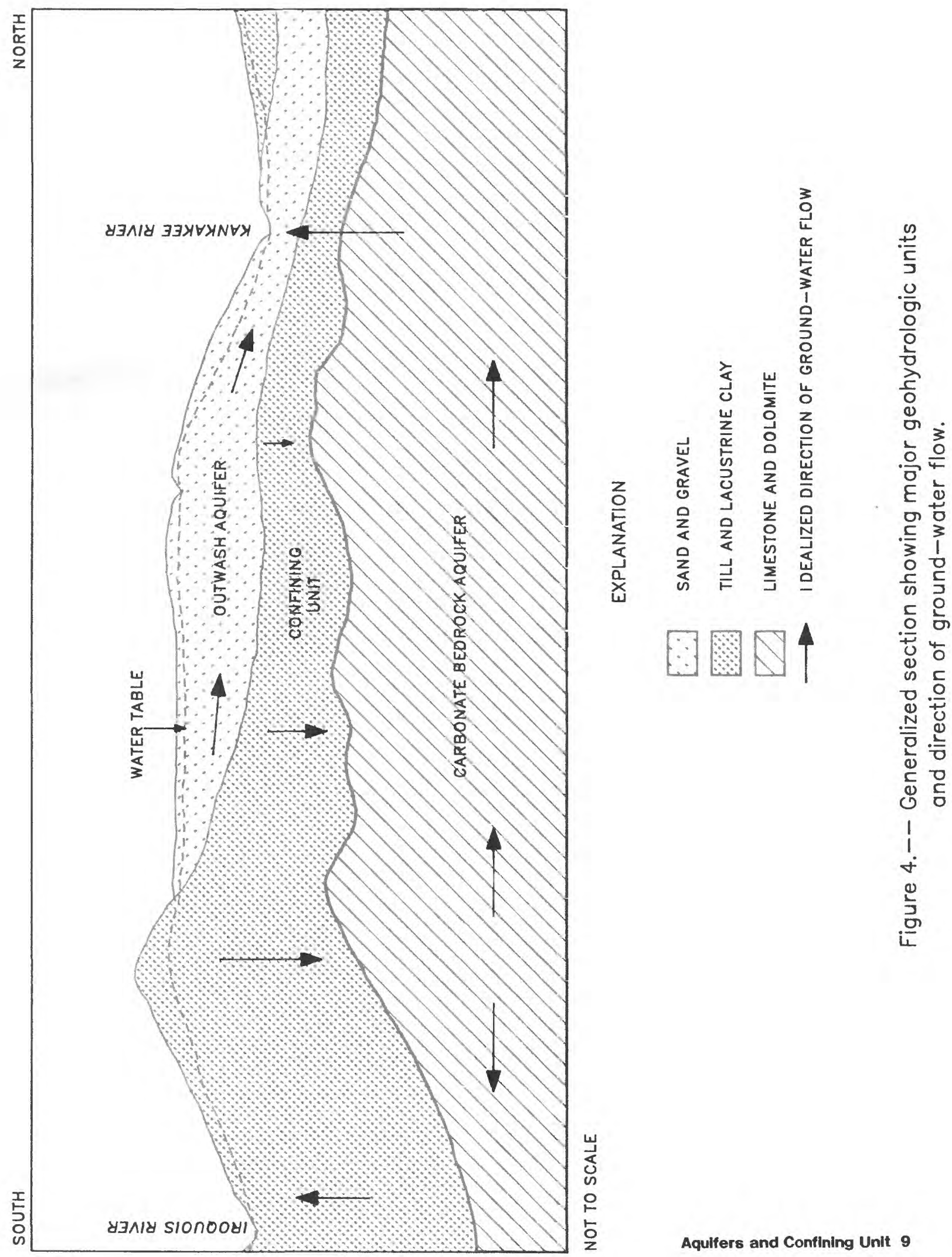


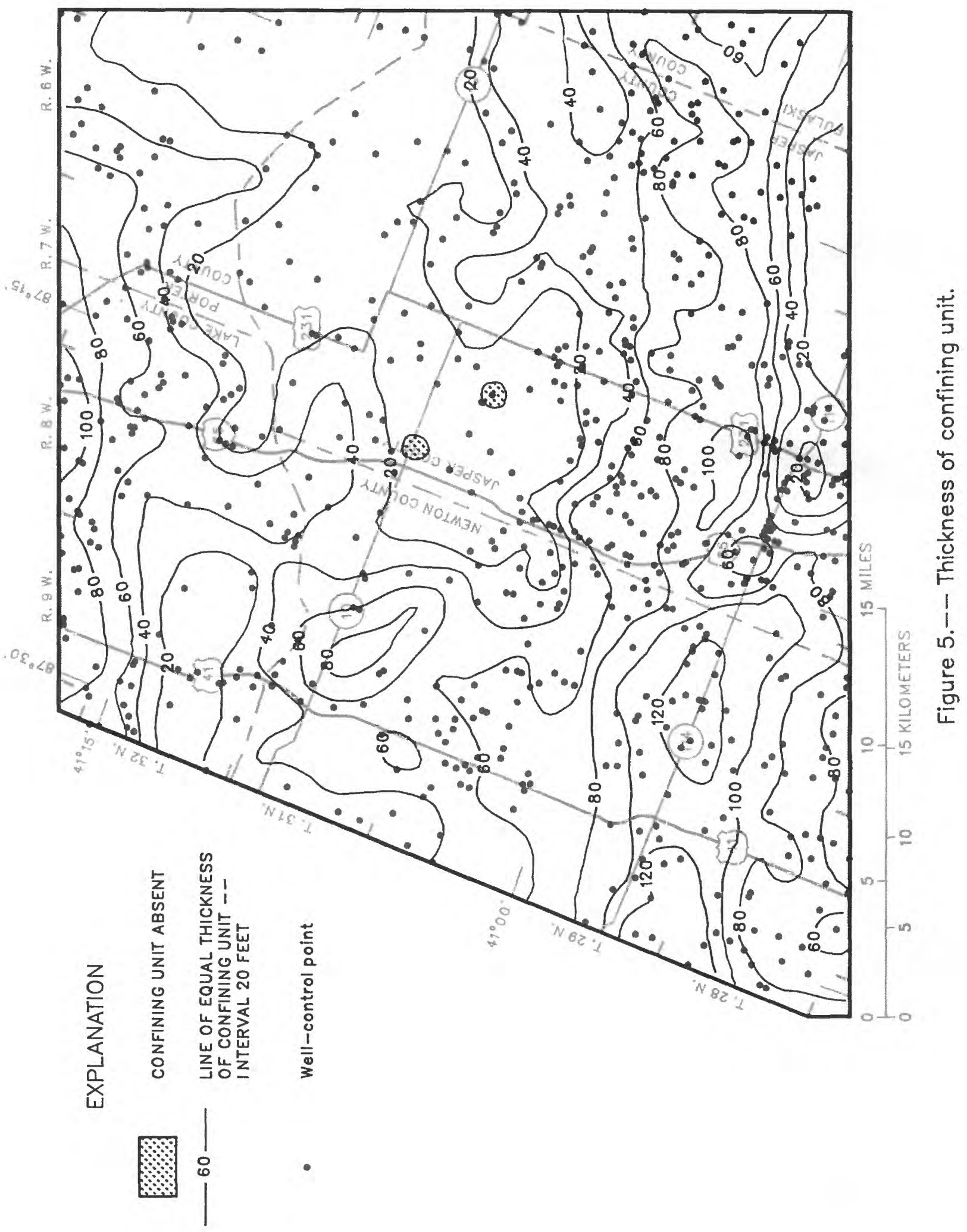




\section{Carbonate Bedrock Aquifer}

Large-capacity wells (yields of greater than $70 \mathrm{gal} / \mathrm{min}$ ) usually derive water from the carbonate bedrock aquifer because a greater drawdown can be developed in the bedrock aquifer than in the outwash aquifer. The bedrock aquifer is used as a source of water for stock, homes, public supply, and irrigation in the study area. Wells completed in the bedrock aquifer generally are less than $300 \mathrm{ft}$ deep, and their yields are variable owing to the distribution of open fractures in the bedrock. Yields from 10 to $2,200 \mathrm{gal} / \mathrm{min}$ have been reported on well logs on file with the Indiana Department of Natural Resources.

In southwestern Newton County and northeastem Jasper County, shale of Devonian and Mississippian age and limestone, shale, and sandstone of Mississippian age are a source of water (fig. 2). Yields of wells tapping these minor bedrock aquifers range from 1 to $15 \mathrm{gal} / \mathrm{min}$.

Because of local fractures in the carbonate bedrock, estimation of transmissivity for the bedrock aquifer was difficult. Transmissivity values were calculated from specific-capacity data on about 130 driller's logs with a method discussed by Brown (1963, p. 336 to 338). The bedrock aquifer was assumed to have a ratio of horizontal-to-vertical hydraulic conductivity of 1:1. The $1: 1$ ratio was used because limestone in quarries in Indiana consistently display relatively equal horizontal and vertical fracturing in the upper 30 to $50 \mathrm{ft}$ of the bedrock. This upper zone also is assumed to be most transmissive because the fractures are larger than those below this zone. Nearly all wells penetrate at least $30 \mathrm{ft}$ of carbonate aquifer and can, therefore, be assumed to be fully penetrating. Any vertical anisotropy that does occur would not greatly affect calculation of transmissivity because almost all flow to the wells is horizontal. The assumptions used to calculate hydraulic characteristics of the carbonate bedrock aquifer are similar to those used in other reports from Indiana (Lapham, 1981, p. 31; Arihood, 1982, p. 26). The assumptions appear reasonable because transmissivities did not have to be changed during model calibration to reasonably simulate measured water levels. Calculated transmissivities ranged from about 10 to $60,000 \mathrm{ft}^{2} / \mathrm{d}$.

A regional description of transmissivity was considered appropriate because of the size of the study area. Extremely small and large values of transmissivity at specific sites do not represent the regional trend in effective transmissivity for the bedrock aquifer. Regional pumpage is affected somewhat by local variations in transmissivity, but more generally by average transmissivity of the aquifer. To reflect the local variability as well as average conditions, transmissivity of the bedrock aquifer was described by a range that represented the central tendency of the available data. Twenty percent of the transmissivity values were less than $1,000 \mathrm{ft}^{2} / \mathrm{d}$ and 80 percent were less than $5,000 \mathrm{ft}^{2} / \mathrm{d}$. A range of 1,000 to $5,000 \mathrm{ft}^{2} / \mathrm{d}$ was considered appropriate to describe regional transmissivity of the carbonate bedrock aquifer. This range is similar to that reported by Watkins and Rosenshein (1963, p. B11-B14) and Rosenshein and Hunn (1968, p. 10). Specificcapacity data indicate that the minor bedrock aquifers composed of shale have a transmissivity of about $500 \mathrm{ft}^{2} / \mathrm{d}$. Ranges of transmissivity in the carbonate bedrock and shale aquifers presented in figure 6 were considered representative of regional conditions. The median transmissivity value of about $2,000 \mathrm{ft}^{2} / \mathrm{d}$ for the carbonate bedrock aquifer was considered an appropriate measure of the central tendency of transmissivity for the carbonate bedrock aquifer because large outlier transmissivity values excessively affected the mean value.

No data for estimating the storage coefficient of the bedrock aquifer were collected during the study. The storage coefficient in nearby Lake County has been estimated by Rosenshein and Hunn (1968, p. 11) to be 0.0008 . Watkins and Rosenshein (1963, p. 11-14) reported a storagecoefficient range from 0.00001 to 0.002 for nine values in Miami County, $25 \mathrm{mi}$ southeast of the study area. For this study, the bedrock storage coefficient was assumed to be the value used by Bergeron (1981, p. 15) of 0.00013 , which is an average of the 10 values just described. 


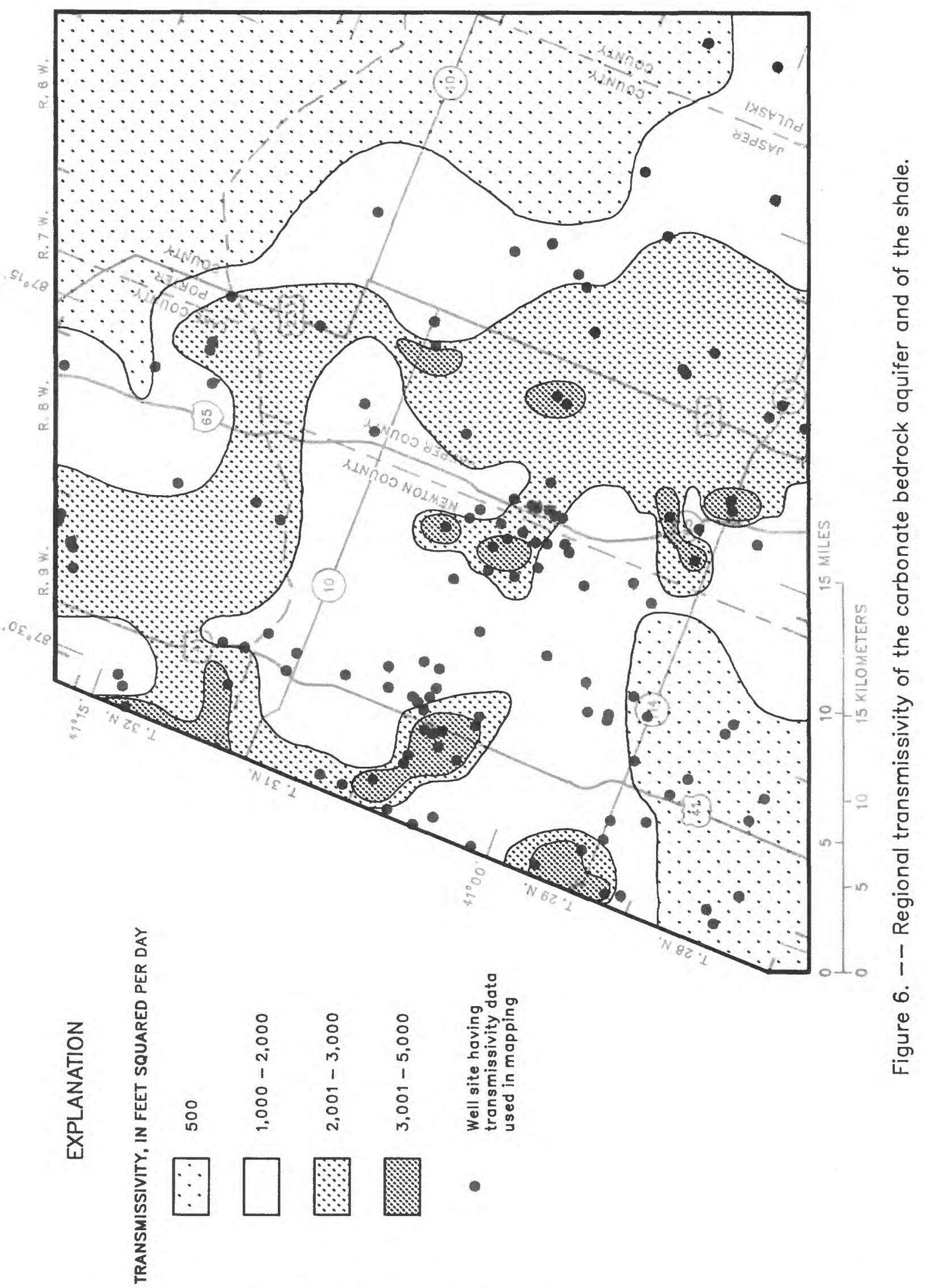

12 Geohydrology and SImulated Ground-Water Flow, Northwestern Indlana 


\section{Ground-Water Flow}

\section{Flow Paths}

The first observation well in the study area was installed in Newton and Jasper Counties by the Indiana Department of Natural Resources and the U.S. Geological Survey to monitor water levels in the two major aquifers - the outwash and the carbonate bedrock aquifers. Thirteen wells have been added to the network over time. Water levels were measured daily to help define the groundwater-flow system. Bergeron (1981, p. 39 and 40) provided representative, steady-state, water-level maps of the outwash and carbonate bedrock aquifers. A water-level map of the bedrock aquifer showing the effect of irrigation pumpage on the flow system is included in the section, "Transient Calibration to the Irrigation Season of 1988." Generalized directions of ground-water flow are shown in figure 4. The outwash aquifer is recharged by precipitation infiltrating through the unsaturated zone. Water flows laterally in the outwash aquifer within the saturated zone to the streams. The confined bedrock aquifer is recharged by downward flow from the outwash aquifer through the confining unit. In the vicinity of major streams, ground water flows upward from the confined bedrock aquifer to the streams (fig. 4). Water flows across the northern, eastern, and western boundaries of the study area through the outwash aquifer and across all boundaries through the bedrock aquifer. The amount of water that flows across boundaries is discussed in the section "Transient Calibration to the Irrigation Season of 1986."

\section{Ground-Water Recharge and Discharge}

Streams receive ground-water discharge from the carbonate bedrock and outwash aquifers. Streams flowing on the outwash deposits receive water from the outwash aquifer, the major streams also receive some water from the carbonate bedrock aquifer. Streams in the Iroquois morainal deposits receive water mostly from the bedrock aquifer. Streams in the Valparaiso morainal deposits receive water from both aquifers.
Because the confining unit beneath the outwash aquifer impedes the downward movement of ground water to the carbonate bedrock aquifer, most recharge entering the ground-water system flows through and discharges from the outwash aquifer to streams. Recharge, however, is constantly available to the bedrock aquifer from the outwash aquifer because the outwash aquifer is always saturated. Recharge from the outwash aquifer to the bedrock aquifer is a function of the vertical hydraulic conductivity of the confining unit and of the vertical hydraulic gradients inducing downward flow. This study concentrates on the bedrock aquifer, therefore, determining appropriate recharge rates for the outwash is less critical than in other hydrologic settings in understanding ground-water availability in the bedrock. Recharge rates to the outwash aquifer are presented so that any ground-water development can be compared to total available water in the system at different times of the year.

Recharge rates vary from year to year. In 1978, Bergeron (1981, p. 35) simulated measured water levels and streamflows with his model by using a recharge rate of $12 \mathrm{in} / \mathrm{yr}$ to the outwash aquifer. Ground-water levels were generally $1.3 \mathrm{ft}$ higher in June 1986 than in June 1978. The additional $1.3 \mathrm{ft}$ is the equivalent of an additional 2 in. of recharge in June 1986, as explained in the section "Steady-State Calibration." Because precipitation was near normal during the recharge periods of 1978 and 1986,12 to $14 \mathrm{in} / \mathrm{yr}$ of recharge is considered representative of annual recharge to the ground-water flow system. This is the quantity of water that recharged the groundwater system by late spring of each year. A conservative recharge rate also can be determined by calculating the rate that would maintain groundwater levels near their annual low values.

Streamflow was measured in August 1986 as part of a gain/loss study. By August, most of the recharge to the ground-water system that occurs from fall to spring has discharged to local streams. Calculation of a recharge rate from streamflow measurements made in August result in recharge rates that reflect the water remaining in the aquifers. Such rates are sometimes described 
as conservative estimates of recharge because they are based on a quantity of water in the aquifer that is exceeded most of the time. Water-resource managers usually can expect this quantity of water to be available for withdrawal, even if the withdrawal occurs during the annual lows for ground-water levels. A conservative estimate of ground-water availability was calculated with about 40 streamflow measurements made August $19-20,1986$. The streams, measuring points, and streamflow gains/losses are shown in figure 7. The streamflow duration at this time was about 80 percent at the streamgaging station on the Kankakee River at Shelby; there had been no rain for 3.5 weeks. Streamflows at an 80-percent flow duration represent base flow. Stream-seepage data then were converted into recharge (table 1 ) by converting measured discharge to recharge. Specifically, the numbers in table 1, which are measured gains along the stream, were converted into inches of recharge over the surface-drainage area associated with the measurement site. Surface-water diversions and additions were accounted for in the calculations.

Table 1. Estimates of recharge to unconsolidated deposits

\begin{tabular}{lc}
\hline $\begin{array}{c}\text { Hydrogeologic unit } \\
\text { (fig. 3) }\end{array}$ & $\begin{array}{c}\text { Recharge } \\
\text { (inches per year) }\end{array}$ \\
\hline Outwash aquifer & 4.9 \\
Valparaiso end moraine & 1.8 \\
Iroquois end moraine & .7 \\
\hline
\end{tabular}

A recharge value was calculated for each hydrogeologic unit listed in table 1 by first assigning the approximately 40 streamflow measurements to the unit upon which the measured stream flows. For example, all flows for streams whose basins lie within the outwash aquifer were grouped together. Then each streamflow in the group was divided by its drainage area to obtain a value of discharge per square mile for the outwash aquifer. An average discharge per square mile was calculated for the aquifer, and then that average was converted into inches per year and entered into table 1.
The numbers in table 1 reflect the depleted availability of water in the two aquifers, owing to time of year and to seasonal bedrock pumpage. The low-permeability confining unit that separates the bedrock aquifer from the outwash aquifer delays the effect of pumpage in the bedrock aquifer on depletion of streamflow. Therefore, the recharge rates in table 1 are not expected to significantly reflect depletion by pumpage.

\section{Ground-Water Withdrawals}

\section{Domestic, Municipal, and Industrial Withdrawals}

Newton and Jasper Counties are predominantly rural areas where individual wells constitute the primary source of domestic water supply. Some communities, however, depend on a central public-water supply. In 1986, about $1.7 \mathrm{Mgal} / \mathrm{d}$ of public water was supplied to an estimated 14,160 people in Newton and Jasper Counties (Indiana Department of Natural Resources, written commun., 1988) (U.S. Department of Commerce, Bureau of the Census, 1986, p. 48 and 53). The remainder of the estimated population $(26,000)$ pumped an estimated $2.1 \mathrm{Mgal} / \mathrm{d}$ from individual domestic wells (based on 80 gallons per day per person). Domestic pumpage is scattered and probably does not measurably affect the ground-water system at any one location. Industrial pumpage in the two counties was estimated to be $0.3 \mathrm{Mgal} / \mathrm{d}$ in 1986 (Siavash Beik, Indiana Department of Natural Resources, written commun., 1988).

\section{Irrigation Withdrawals}

Irrigation as practiced in the study area is typical of crop production in the humid climate of the upper midwestern United States. Irrigation protects against crop failure during periods of inadequate precipitation. Crops that are irrigated include corn, soybeans, potatoes, onions, mint, and blueberries. 


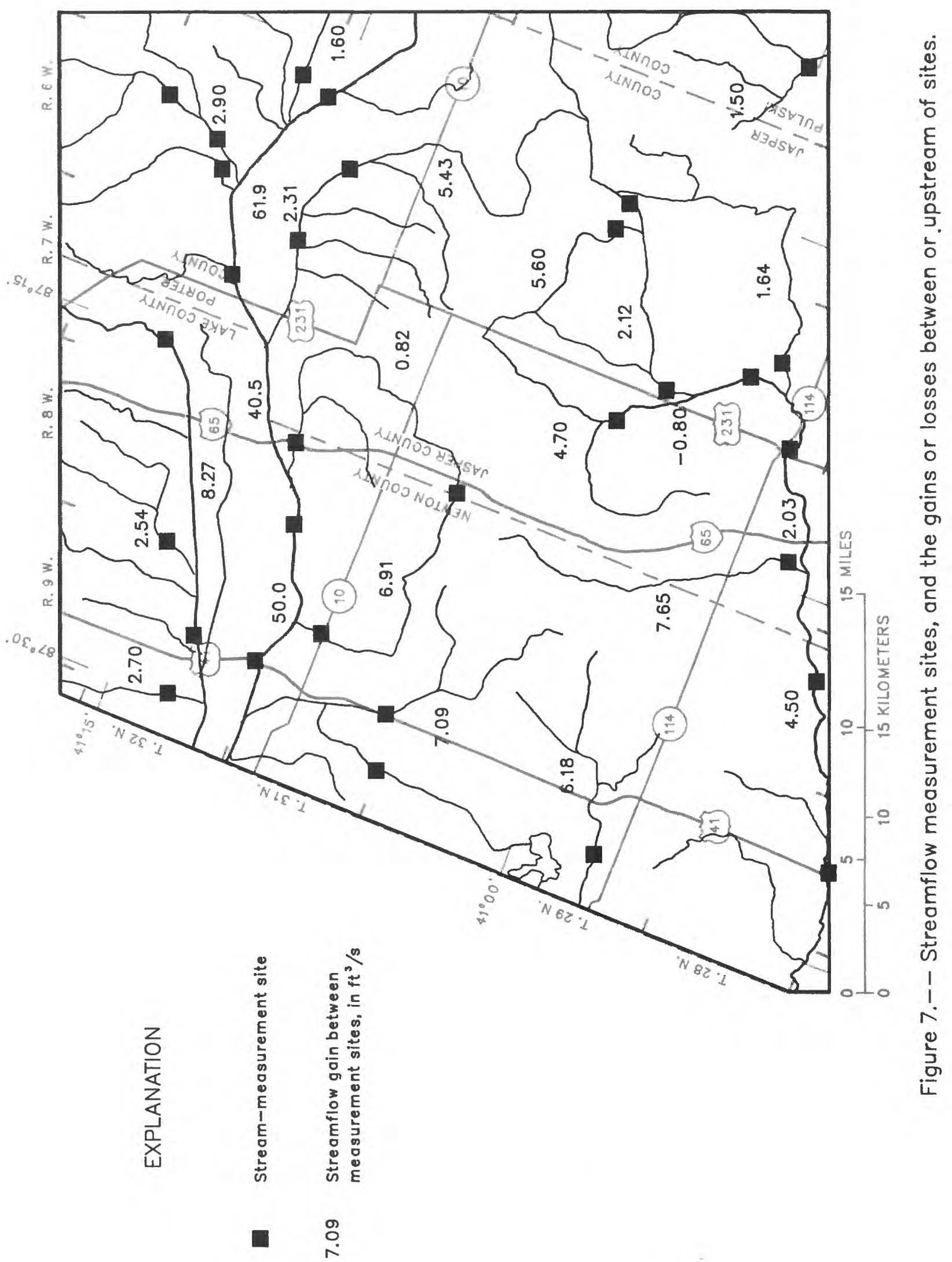


Surface and ground water are used for irrigation, but this study focuses on the effects of irrigating with ground water. In July 1986, during the irrigation season, about 80 percent of the ground-water pumpage for irrigation was from the carbonate bedrock aquifer (Siavash Beik, Indiana Department of Natural Resources, written commun., 1988).

Significant withdrawals (greater than $100,000 \mathrm{gal} / \mathrm{d}$ ) are made in the study area (fig. 8), but most of the irrigation is in the northern twothirds of the study area. Farming in this area requires irrigation because the soils have developed on coarse outwash deposits and windblown sands that have limited soil-moisture capacity and are easily drained. Water levels in these areas decline rapidly during periods of low rainfall and high temperature. Soils in the southern one-third of the study area have developed on till and lacustrine deposits. The large clay content of these soils help to retain moisture, and crops are not irrigated in this area.

The largest withdrawals for irrigation are made during June, July, and August. Irrigation withdrawals in the study area during these 3 months in 1986 was $10.0,40.5$, and $40.6 \mathrm{Mgal} / \mathrm{d}$, respectively.

\section{Ground-Water-Level Fluctuations}

Water levels fluctuate daily and seasonally in wells that penetrate the outwash and bedrock aquifers in response to variations in recharge, pumpage, and barometric pressure. Hydrographs of selected observation wells completed in these aquifers show a seasonal trend, with water levels normally highest during the spring and lowest during July and August (fig.9).

Seasonal fluctuations in water levels are partly the result of variation in natural recharge to and discharge from the aquifers. Examination of precipitation data indicate that variation in recharge is not entirely a function of variation in precipitation. Monthly precipitation ranges from a mean of 1.8 in. in February to 4.23 in. in July (National Oceanic and Atmospheric Administration, 1977, p. 4). Bergeron (1981, p. 23) reported that the variation in recharge is largely a function of evapotranspiration. During the growing season, transpiration by shallow-rooted crops and direct evaporation effectively reduce the amount of rainfall that infiltrates downward through the unsaturated zone to the aquifers.

Large seasonal water-level fluctuations in the carbonate bedrock aquifer are caused by agricultural withdrawals and the aquifer's hydraulic characteristics. In the carbonate bedrock aquifer, water levels at observation wells fluctuated from about 5 to $80 \mathrm{ft} / \mathrm{yr}$, depending on the magnitude of withdrawals and location of the well in relation to pumping centers. The large fluctuations are caused by large withdrawals, the small storage coefficient $\left(1.3 \times 10^{-4}\right)$, and the low transmissivity (median value of $2,000 \mathrm{ft}^{2} / \mathrm{d}$ ) of the bedrock aquifer. The hydrograph for Jasper 11 (fig. 9) shows the decline of water-levels in the carbonate bedrock aquifer during the irrigation season.

Seasonal water-level fluctuations in the bedrock aquifer also cause fluctuations in the confining unit. A piezometer located $2 \mathrm{mi}$ west of Parr is screened about $20 \mathrm{ft}$ above the bedrock in the confining unit. The water level in the piezometer declined a maximum of $27 \mathrm{ft}$ during the 1986 irrigation season.

Long-term hydrographs for two wells in the carbonate bedrock aquifer and one well in the outwash aquifer are shown in figure 9. The hydrograph for Jasper 4 does not indicate a trend in water levels; water levels at Jasper 11 have a slightly downward trend. Whether this trend will continue depends on recharge rates and groundwater use.

\section{SIMULATION OF GROUND-WATER FLOW}

A three-dimensional, finite-difference digital model developed by McDonald and Harbaugh (1984) was used to simulate flow in the groundwater system and to evaluate the effects of increased irrigation pumpage on the hydrologic system in parts of Newton and Jasper Counties and adjacent areas of northwestern Indiana. The model solves ground-water-flow equations for steady or nonsteady flow in an anisotropic, heterogeneous, multiaquifer, ground-water-flow system. 


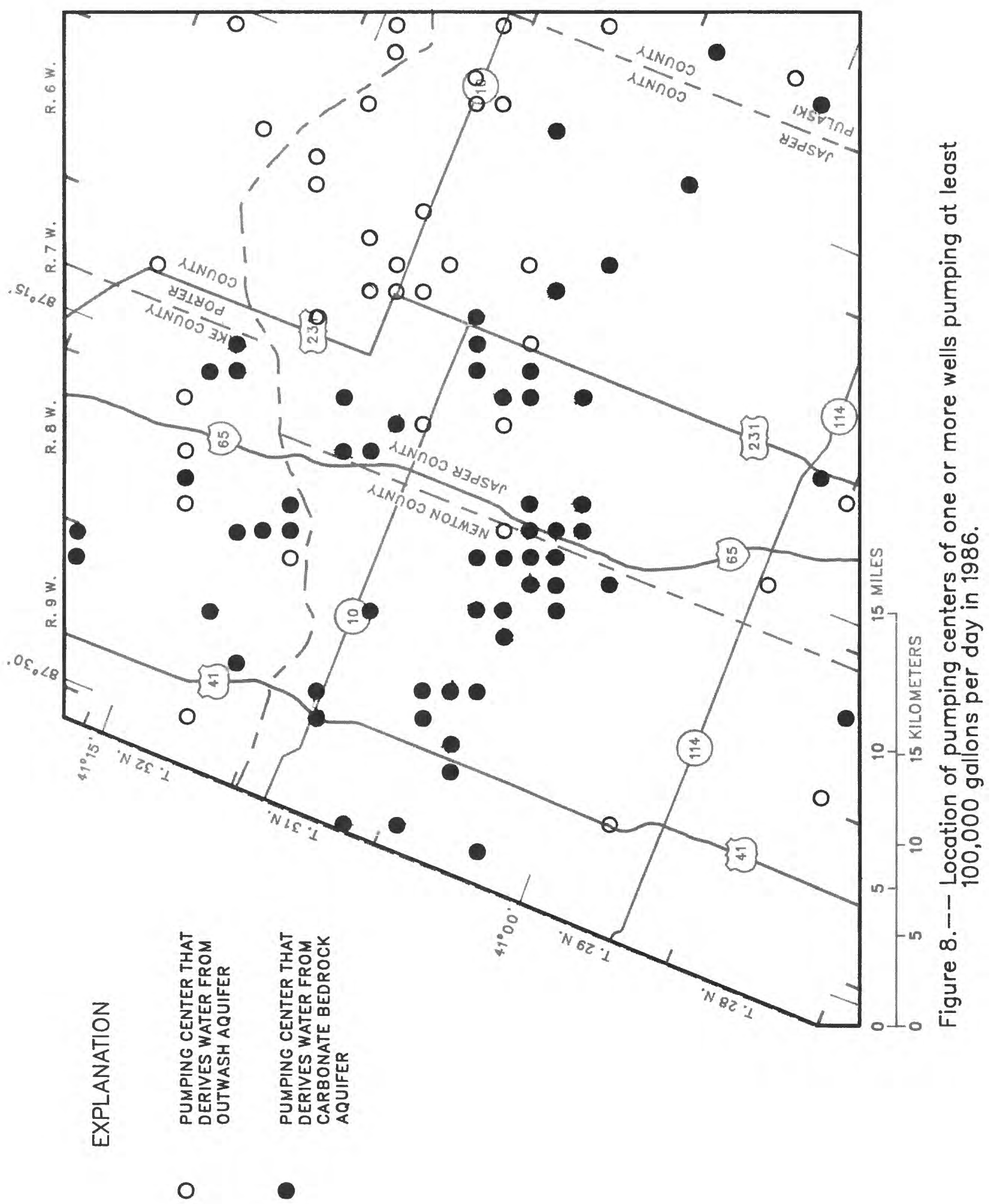




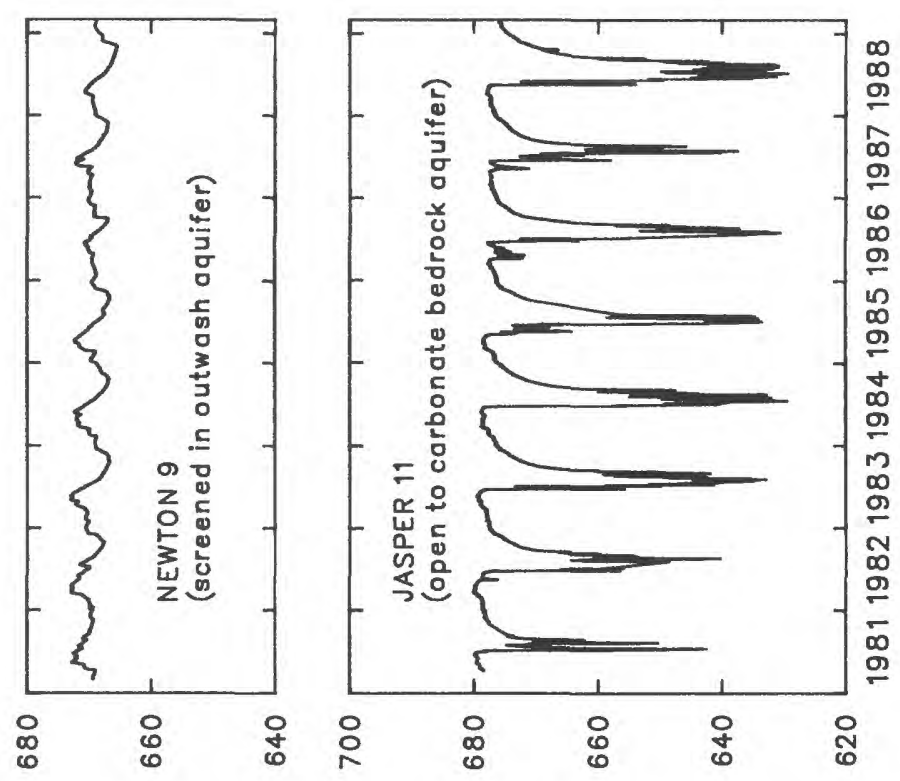

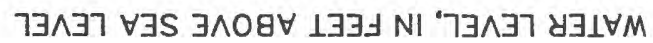
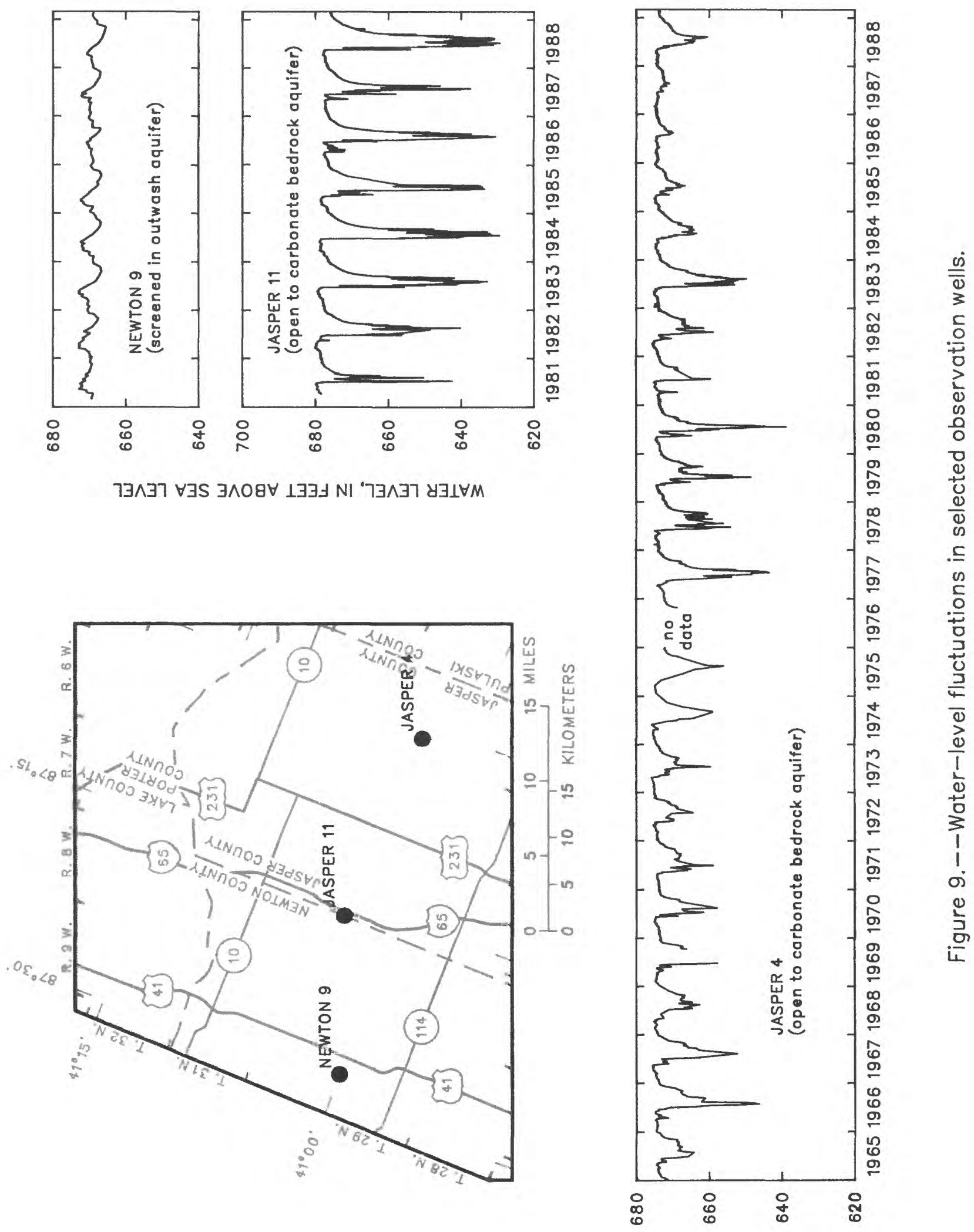

\urcorner$\exists \wedge \exists\urcorner \forall \exists S \exists \wedge O 8 \forall$ $1 \exists \exists \unlhd \mathrm{NI} ` 7 \exists \wedge \exists 7$ 봅 


\section{Simplifying Assumptions}

The following simplifying assumptions were made for the geometry, hydraulic properties, and other characteristics of the ground-water system:

(1) The hydraulic conductivity of the outwash aquifer was uniform, vertically and horizontally.

(2) Vertical hydraulic conductivity of the silt-clay confining unit was uniform, vertically and horizontally.

(3) The hydraulic conductivity of the bedrock aquifer was uniform, vertically but not horizontally.

(4) The thickness of streambeds was $1 \mathrm{ft}$. The calibrated value of streambed vertical hydraulic conductivity was based on a $1-\mathrm{ft}$ bed thickness.

(5) Water levels at the beginning of June 1986 (before the irrigation season) represented a steady-state condition.

(6) Irrigation water did not return to the ground-water system.

\section{Design of the Model}

The digital model was based on a square block-centered grid network that covered the entire $987 \mathrm{mi}^{2}$ study area (fig. 10). The grid network, aligned southwest-northeast, paralleled the orientation of the Kankakee River and the Valparaiso and Iroquois end moraines. The grid ( $30 \mathrm{mi}$ by $38 \mathrm{mi}$ ) was composed of 1,140 one-milesquare blocks.

Flow in the three major geohydrologic units (outwash aquifer, confining unit, and carbonate bedrock aquifer) was simulated in the model by nine layers connected by vertical leakage (fig. 11). Either one or three layers represented the outwash aquifer. In areas where the Valparaiso endmoraine overlays the outwash aquifer, two layers represented the moraine and one layer represented the outwash aquifer. In areas where the end moraine is absent, the two layers representing the moraine continued into the outwash aquifer, which is then represented by three layers (fig. 11). The next five layers represented the confining unit and were used to account for the change in water level observed vertically through the confining unit during the irrigation season. The bottom layer represented the bedrock aquifer. Layer 1 , the top layer, represented the unconfined section of the outwash aquifer. Layers 2 through 6 were confined, and layers 7 through 9 were either confined or unconfined.

Initial values for model parameters generally were obtained from the calibrated model developed by Bergeron (1981). The transmissivity of the carbonate bedrock aquifer, however, was recalculated because additional data have been collected since Bergeron's study. Transmissivity of the carbonate bedrock aquifer was calculated by use of specific-capacity data from water-well driller's logs, as described in the section titled "Carbonate Bedrock Aquifer."

River and drain nodes (McDonald and Harbaugh, 1984, p. 209 and 288) were used in the model to represent the streams shown in figure 1. A total of 109 river nodes was used to simulate the Kankakee and Iroquois Rivers and 4 other streams around the edge of the model where the streamflow was large enough to supply water to the groundwater system. A total of 318 drain nodes was used to simulate the smaller streams. Drain nodes receive ground-water discharge but do not recharge the ground-water system. Drain nodes represent small streams that cease to flow when the water table declines below the bottom of the stream.

Boundary conditions in the ground-water model were selected so that the type and the location of the boundary would have a minimal effect on the result of imposed pumping in the model. In general, boundary conditions were the same for all model layers, and the boundaries were placed far from major pumping centers so that they would have minimal effects on pumpage. On the north was a constant-head boundary, located about 10 mi north of the Kankakee River (fig. 10). The eastern boundary of the model, also a constant-head boundary, was placed at least $5 \mathrm{mi}$ east of the western edge of the Mississippian and Devonian shale (fig. 2) where little or no pumping 


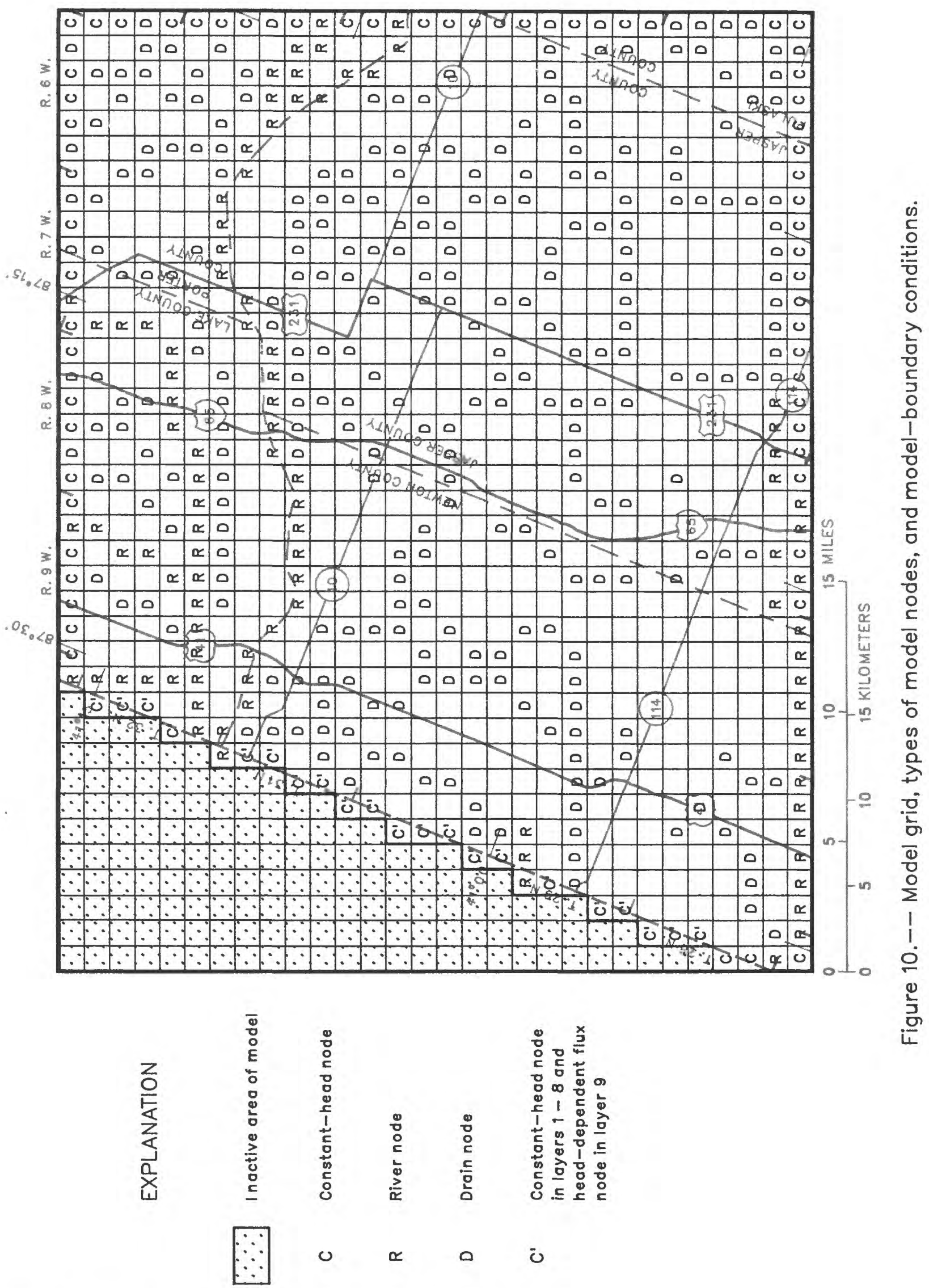




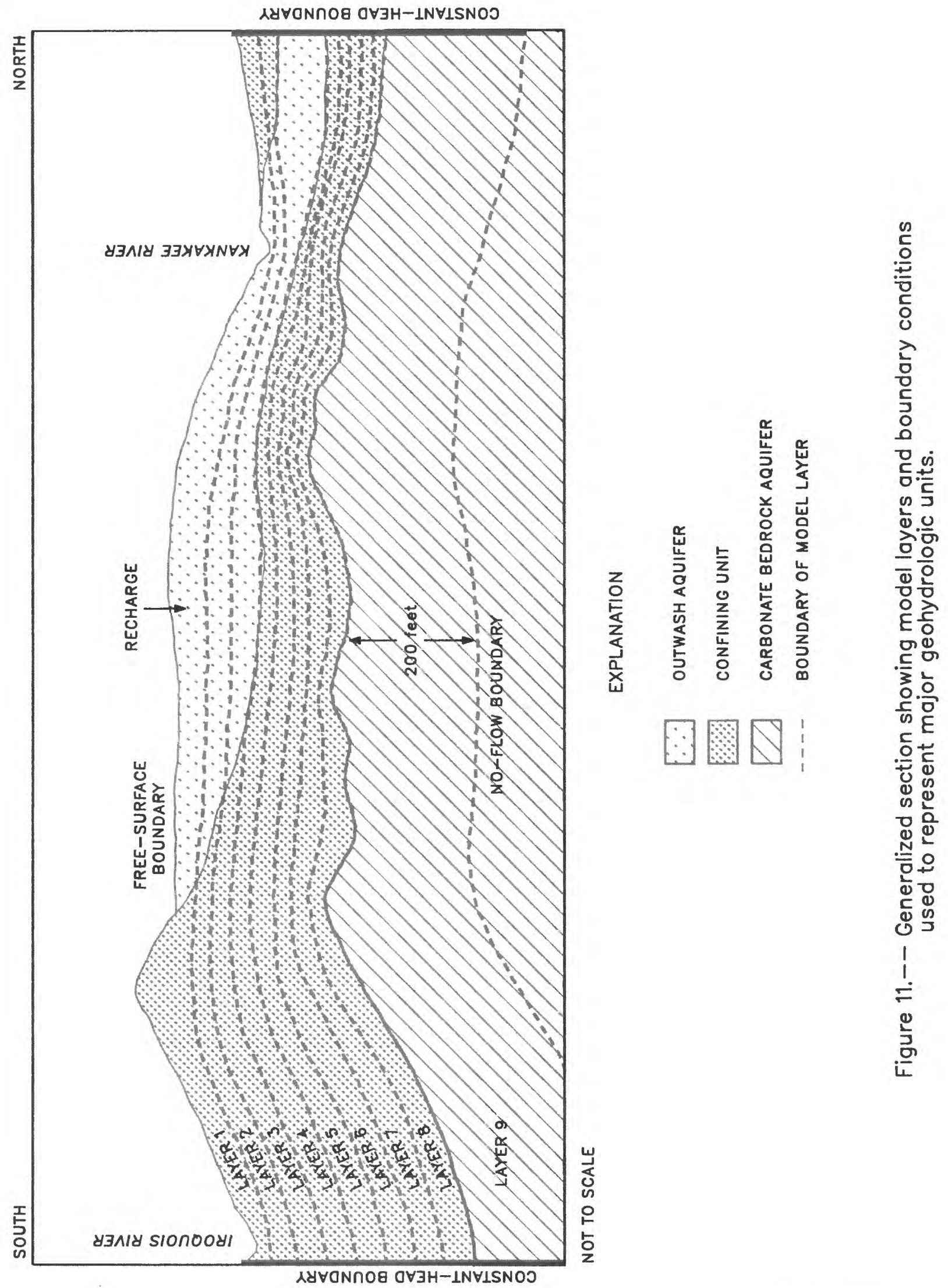


from the bedrock occurs. The boundary along the southern end of the model was a specified-head boundary along the Iroquois River (fig. 1) and a constant-head boundary east of the Iroquois River. The western boundary of the model coincided with the Indiana-Illinois State line and was modeled as a constant-head boundary for layers 1 through 8 .

Layer 9 was modeled as a head-dependent flux boundary along the western boundary. A constant-head boundary would have been used for layer 9 as well, but only the head-dependent flux boundary allows heads to change through the simulation. Declining heads through the irrigation season are important to simulate because of the water-level declines caused by significant pumping in the carbonate bedrock aquifer near the state line in Illinois. Water levels along the western boundary, by which fluxes were calculated, were varied throughout the irrigation season according to water-level data supplied by the Illinois State Water Survey. Data from 1987 were used because the data set is more complete than the 1986 data set, and because the general pattern of water-level decline each year is similar. A no-flow boundary was assumed below the bottom layer of the model where the bedrock was not considered significantly fractured. A free-surface boundary represented the water table in the uppermost active layer.

Recharge was simulated differently for different periods of the year. Recharge from fall to spring, when nearly all recharge occurs, causes ground-water levels to rise until they reach near steady-state conditions in the spring. Instead of simulating the rise of water levels, this recharge was incorporated into the model by use of spring water levels as initial conditions for the simulation. A small amount of recharge occurred subsequent to initial conditions. For this period, rises in hydrographs for the outwash aquifer were used as an estimate of recharge. For example, during June the rise in hydrographs indicated 0.5 inches of recharge should be input to the model for that month. Usually, the hydrographs indicated no recharge occurred.

\section{Calibration of the Model}

\section{Steady-State Calibration}

The purpose of the steady-state calibration was to compute steady-state water levels that could be used as initial water levels for the transient calibration. The steady-state calibration also resulted in a set of initial estimates for model parameters, such as transmissivity of the bedrock aquifer and hydraulic conductivity of the outwash aquifer. Final, more accurate estimates of model parameters were determined from the transient calibration when the ground-water system is stressed by large pumping rates during the irrigation season.

Steady-state calibration required an estimate of recharge to the outwash aquifer that maintained water levels near the steady-state values measured during June 1986. Bergeron (1981) determined that a recharge rate of $12 \mathrm{in} / \mathrm{yr}$ produced groundwater discharges to streams similar to values measured during a gain/loss study done in June 1978. More than $12 \mathrm{in} / \mathrm{yr}$ of recharge were required for steady-state conditions in 1986 because water levels in the outwash aquifer for June 1986 averaged $1.3 \mathrm{ft}$ higher than in June 1978. Assuming a specific yield of 0.12 (Bergeron's calibrated value), a water-level increase of $1.3 \mathrm{ft}$ is equivalent to an additional recharge rate of 2 in. for 1986 . Therefore, $14 \mathrm{in} / \mathrm{yr}$ of recharge were assumed for the steady-state calibration of June 1986.

Assuming $14 \mathrm{in} / \mathrm{yr}$ of recharge, the hydraulic conductivity of the outwash aquifer and vertical hydraulic conductivity of the confining unit were adjusted until simulated water levels agreed closely with measured values of June 1986 and until further adjustments to parameter values did not significantly improve this agreement. Both the absolute difference between simulated and measured water levels and the mean of positive and negative differences were minimized. For steadystate calibration, the mean absolute error was 
$2.5 \mathrm{ft}$ for 21 simulated water levels for the outwash aquifer, and $3.3 \mathrm{ft}$ in 18 simulated water levels for the carbonate bedrock aquifer. Average bias (B) in simulated water levels was calculated as:

$$
\mathrm{B}=\underline{\Sigma \text { (simulated water levels - measured water levels) }}
$$

total number of observations

By use of this equation, simulated water levels for June 1986 averaged about $1 \mathrm{ft}$ lower than measured water levels in the outwash aquifer and averaged about $0.4 \mathrm{ft}$ higher than measured water levels in the bedrock aquifer.

\section{Transient Calibration to the Irrigation Season of 1986}

After the steady-state calibration was completed, a transient-model calibration was prepared to simulate water-level declines caused by irrigation withdrawals. The 4-month simulation period was divided into four stress periods in which all stresses on the ground-water system were held constant during the period. The four stress periods corresponded to the months of June, July, August, and September 1986 . Because withdrawals were less in June and September and because less detailed simulated water levels were required, the two stress periods associated with those months were divided into four time steps. Each time step was equal to 1.5 times the length of the previous time step. The July and August stress periods were divided into eight time steps with the same pattern of increasing length as the June and September stress periods.

Hydrographs of simulated and measured water levels for the June-September 1986 transient calibration are shown in figure 12. The hydrographs were chosen because the record for the measured water levels was complete and because the hydrographs show typical results of the transient calibration. The hydrographs of simulated water levels do not show the detail of fluctuation seen in the hydrographs of measured water levels because only monthly pumpage data were available for the calibration and only a few water levels were calculated for each stress period. The simulated water levels, however, followed the same trends as the measured water levels.

Agreement between simulated and measured water levels seemed reasonable for the transient calibration. The mean absolute error in simulated water levels was $2.4 \mathrm{ft}$ for 21 sites in the outwash aquifer, and $5.0 \mathrm{ft}$ for 14 sites in the carbonate bedrock aquifer. On the average, the simulated water levels were $1.3 \mathrm{ft}$ below measured water levels in the outwash aquifer, and $0.45 \mathrm{ft}$ below measured water levels in the carbonate bedrock aquifer. During transient calibration, the effect of each model parameter on the ground-water-flow system was evaluated. The parameter that most affected simulated water levels was the vertical hydraulic conductivity of the clay confining unit. The confining unit has a small vertical conductivity and, therefore, it is the component of the groundwater system that controls the leakage rates from the outwash aquifer to the bedrock aquifer. By controlling leakage rates, the confining unit also greatly affects drawdowns in the bedrock aquifer. See the section titled "Sensitivity Analysis and Evaluation" for a quantitative description of the effect of vertical hydraulic conductivity on water levels.

The effects of pumping from the bedrock aquifer on water levels in the outwash aquifer were evaluated. The different values for vertical hydraulic conductivity that were tested caused only a slight change in the slope of the hydrographs for the outwash aquifer. The change was noticeable only if the hydrographs from different simulations (different vertical hydraulic conductivities) for the same well were overlain. The implication of the small change in slope is that, although the outwash aquifer is a source of water for the bedrock aquifer, the additional discharge of water from the outwash aquifer caused by pumping from the bedrock 

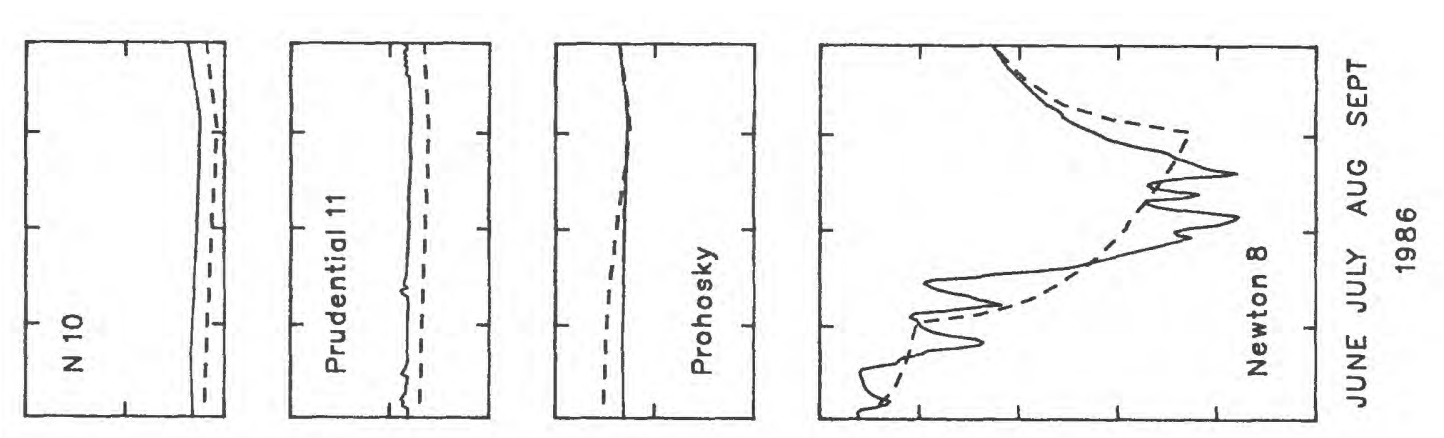

$\dot{\circ}$
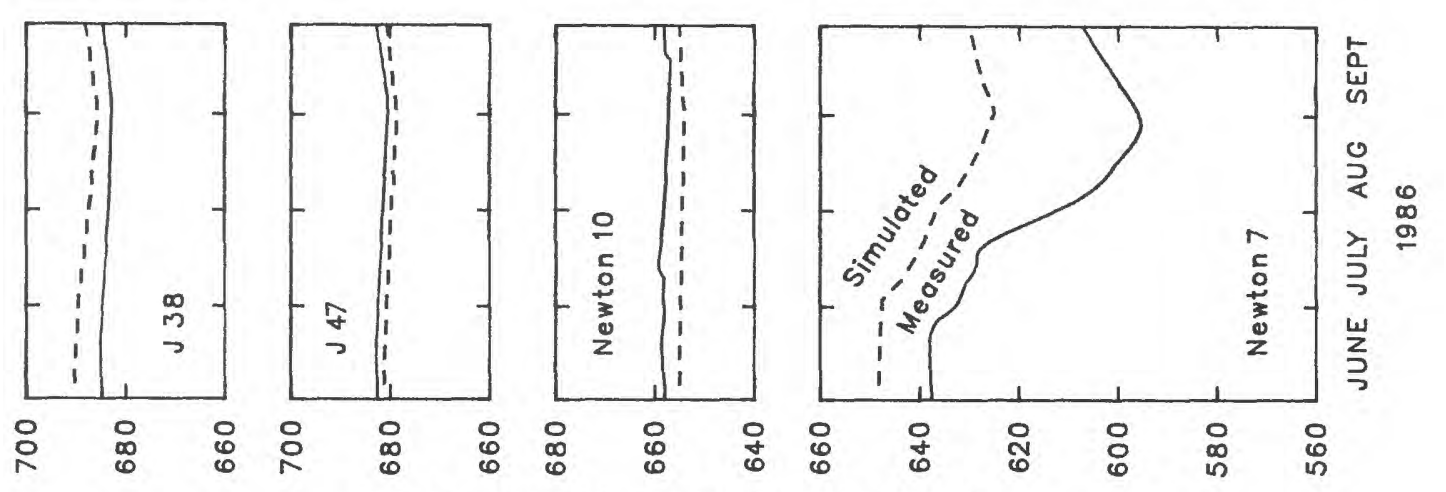

$7 \exists \wedge \exists 7 \forall \exists S \exists \wedge 08 \forall 1 \exists \exists \exists \mathrm{NI}$ ' $7 \exists \wedge \exists 7$ ป $\exists \perp \forall M$
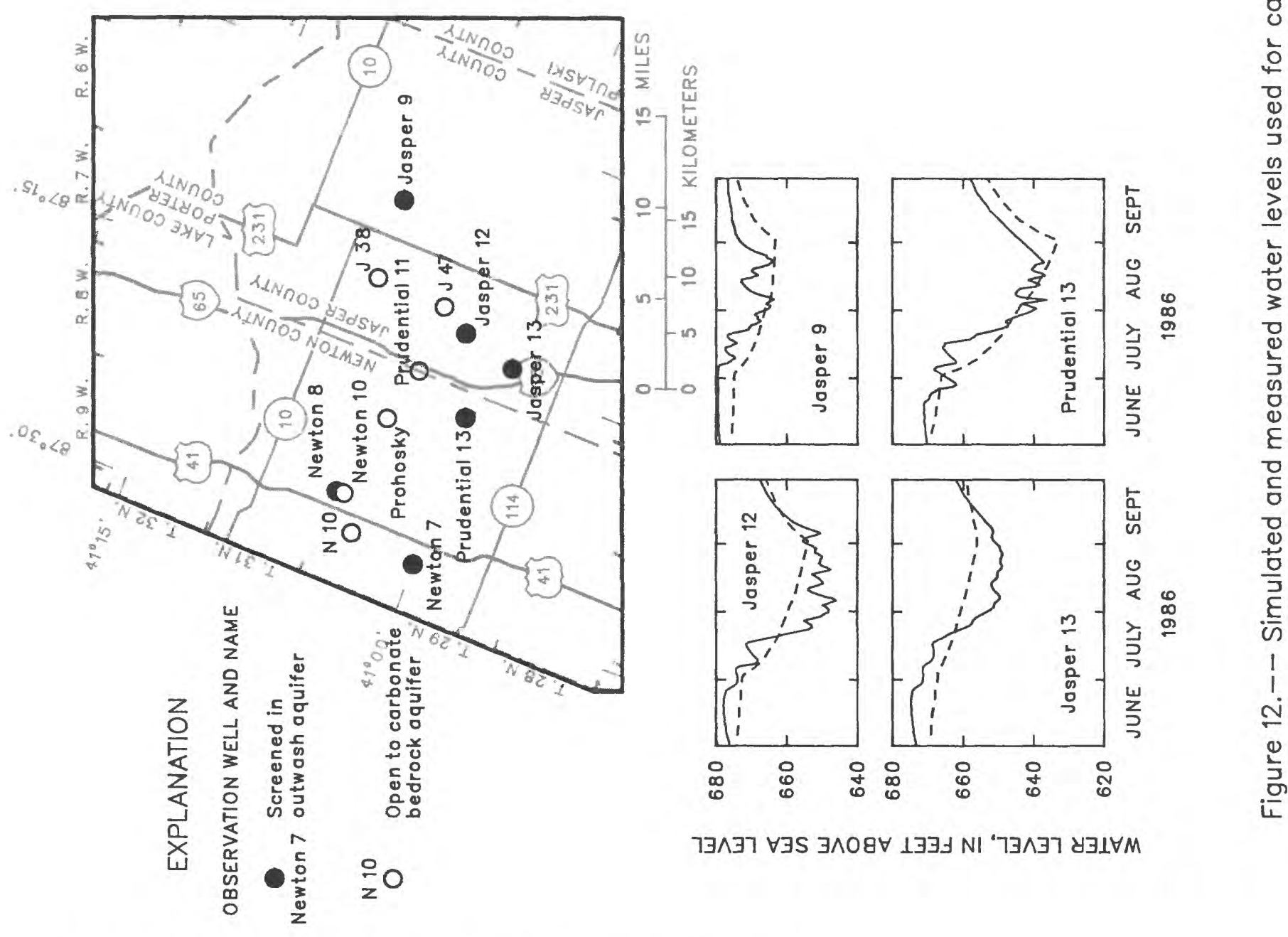
Table 2. Calibrated values of model parameters

[ft/d, feet per day; --, no data]

\begin{tabular}{lcccc}
\hline \multicolumn{1}{c}{ Parameter } & $\begin{array}{c}\text { Calibratod value } \\
\text { used in } \\
\text { current study }\end{array}$ & Range of values tested & $\begin{array}{c}\text { Bergeron's 1981 } \\
\text { calibrated value }\end{array}$ \\
\hline $\begin{array}{l}\text { Horizontal hydraulic conductivity of } \\
\text { outwash aquifer }\end{array}$ & $350 \mathrm{ft} / \mathrm{d}$ & $120-400 \mathrm{ft} / \mathrm{d}$ & $250 \mathrm{ft} / \mathrm{d}$ \\
$\begin{array}{l}\text { Vertical hydraulic conductivity of confining unit } \\
\text { Vertical hydraulic conductivity of streambeds }\end{array}$ & $1.8 \times 10^{-4} \mathrm{ft} / \mathrm{d}$ & $4.0 \times 10^{-5}-0.01 \mathrm{ft} / \mathrm{d}$ & $0.0006-0.004 \mathrm{ft} / \mathrm{d}$ \\
Specific yield of outwash aquifer & $50 \mathrm{ft} / \mathrm{d}$ & $10-250 \mathrm{ft} / \mathrm{d}$ & $0.04-43 \mathrm{ft} / \mathrm{d}$ \\
Specific storage of confining unit & 0.07 & $0.07-0.20$ & 0.12 \\
Storage coefficient of carbonate bedrock aquifer & $1.8 \times 10^{-5} \mathrm{ft}^{-1}$ & $4.0 \times 10^{-6}-0.001 \mathrm{ft}^{-1}$ & -- \\
\hline
\end{tabular}

aquifer does not noticeably affect water levels in the outwash aquifer. The minor effect on water levels is reasonable because of the large specific yield of the outwash aquifer.

The final calibrated model-parameter values and the range of values tested are presented in table 2 along with calibrated values determined by Bergeron (1981) for comparison. The greatest difference in parameter values between the two calibrations was in the vertical hydraulic conductivity of the confining unit. Bergeron's large vertical hydraulic-conductivity value allowed too much water from the outwash aquifer to leak to the bedrock aquifer. The rapid leakage rate lessened the amount of simulated drawdown that developed during the irrigation season. Bergeron did not have sufficient pumpage data and waterlevel records in the area of interest to detect that his vertical conductivity was too large. Additional observation-well and pumpage data were critical in determining a more reasonable vertical conductivity for the current study.

The quantities of flow for each component of the ground-water system before most irrigation pumpage began in late June 1986 are given in table 3. The same quantities for the period of maximum water-level drawdowns in August 1986 are given in table 4 .
Table 3. Water budget determined by transient calibration for June 1986

\begin{tabular}{|c|c|c|c|}
\hline \multicolumn{2}{|c|}{$\begin{array}{c}\text { Inflow } \\
\text { (cubic feet per second) }\end{array}$} & \multicolumn{2}{|c|}{$\begin{array}{c}\text { Outflow } \\
\text { (cublc feet per second) }\end{array}$} \\
\hline Precipitation & 276 & Ground-water pumpage & 18 \\
\hline Storage & 182 & Storage & 8 \\
\hline \multirow[t]{2}{*}{ Boundary inflow } & 65 & $\begin{array}{l}\text { Ground-water } \\
\text { discharge to } \\
\text { streams }\end{array}$ & 489 \\
\hline & & Boundary outflow & 10 \\
\hline Total inflow & 523 & Total outflow & 525 \\
\hline
\end{tabular}

Table 4. Water budget determined by transient calibration for August 1986

\begin{tabular}{|c|c|c|c|}
\hline \multicolumn{2}{|c|}{$\begin{array}{c}\text { Inflow } \\
\text { (cubic feet per second) }\end{array}$} & \multicolumn{2}{|c|}{$\begin{array}{c}\text { Outflow } \\
\text { (cubic feet per second) }\end{array}$} \\
\hline Precipitation & 0 & Ground-water pumpage & e 64 \\
\hline Storage & 273 & Storage & 2 \\
\hline $\begin{array}{l}\text { Ground-water } \\
\text { recharge from } \\
\text { streams }\end{array}$ & 5 & $\begin{array}{l}\text { Ground-water } \\
\text { discharge to } \\
\text { streams }\end{array}$ & 273 \\
\hline Boundary inflow & 69 & Boundary outflow & 11 \\
\hline Total inflow & 347 & Total outflow & 350 \\
\hline
\end{tabular}


Simulated water levels for Newton 7 were above measured values (fig. 12) because of the simulation of water levels from 1987 for conditions in 1986 along the western model boundary. Few water levels from 1986 were available to define the water level along the western boundary. It became apparent that measured water levels in 1987 generally were higher than water levels in 1986. The effects of high water levels used in simulations for the western boundary, however, are not evident in the hydrographs for wells farther east of Newton 7, such as at Newton 8 (see fig. 12).

The error introduced by the constant-head boundary condition does not appear to be significant in areas more than 3 mi east of the western boundary. High simulated water levels along the western model boundary do not propagate far into the modeled area probably because stream levels associated with river and drain nodes generally control water levels in the bedrock aquifer. Water levels in streams just inside the western model boundary tended to adjust a high simulated water level along the western boundary downward to the water level of the stream. Farther east of the streams, simulated water levels were nearer measured levels.

Some interpretations about the ground-water system and its response to withdrawal can be made from tables 3 and 4 . The source of most ground water is from either precipitation or a decrease in storage within the study area and not from flow across the model boundaries. Also, inflow at the boundary of the model was increased by only $4 \mathrm{ft}^{3} / \mathrm{s}$ during irrigation pumpage, indicating little effect from the boundaries on simulated drawdowns. Ground-water pumpage in August 1986 represented 18 percent of the total flow in the system (table 4). Pumpage intercepted $59 \mathrm{ft}^{3} / \mathrm{s}$ of ground water that would have discharged to streams and induced infiltration of only $5 \mathrm{ft}^{3} / \mathrm{s}$ into the ground-water system from streams. The decrease in discharge to streams is due mainly to a lack of ground-water recharge during the summer.

The gain or loss of water along 21 sections of about 20 streams was measured to aid in calibrating the quantity of simulated groundwater discharge. During August 19-20, 1986, 11 measurements were made along small streams in the outwash aquifer, 4 measurements were made along the Kankakee River, and 6 measurements were made along streams in the morainal deposits (see fig. 7). The average simulated and measured discharges to stream sections are given in table 5 .

The data in table 5 indicate that simulated ground-water discharge was not distributed in the same manner as measured discharge. The average simulated discharge to small streams in the outwash aquifer was about twice as much as the average measured discharge. In contrast, the average simulated discharge to the Kankakee River was about one-half that of the average measured discharge. When all stream sections in the outwash aquifer were considered together, the average simulated discharge per stream section was $10.9 \mathrm{ft}^{3} / \mathrm{s}$, and the average measured discharge was $10.8 \mathrm{ft}^{3} / \mathrm{s}$. Therefore, the total quantity of simulated precipitation recharge to the outwash aquifer appears correct, but more of that water is discharged to small streams than should be. The reason that the distribution of measured ground-water discharge in the outwash aquifer is different from that simulated is unknown. Possibly the vertical hydraulic conductivity of the streambed for small streams is less than that for the Kankakee River. Additional model analysis would

Table 5. Average simulated and measured discharge to stream sections for August 19-20, 1986

\begin{tabular}{ccccc}
\hline $\begin{array}{c}\text { Average discharge to small } \\
\text { streams located in the aquifer } \\
\text { (cubic feet per second) }\end{array}$ & $\begin{array}{c}\text { Average discharge to Kankakee River } \\
\text { (cubic feet per second) }\end{array}$ & $\begin{array}{c}\text { Average discharge to streams located in } \\
\text { morainal deposits } \\
\text { (cubic feet per second) }\end{array}$ \\
\hline Simulated & Measured & Simulated Measured & Simulated Measured \\
9.41 & 4.71 & 14.9 & 27.4 & 2.13 \\
\hline
\end{tabular}


be required to test various hypotheses. Although the simulated distribution of discharge is not as accurate as desired, the distribution will have little effect on simulated ground-water flow and pumpage in the bedrock aquifer, which is the focus of the study.

The reason that the distribution of flow to streams is not important to simulations of withdrawals and drawdowns in the bedrock is because of the relation of the outwash to the bedrock. The outwash aquifer is the source of recharge that leaks downward to the bedrock aquifer. The outwash needs only to remain saturated for leakage to occur. The distribution of flow to streams in the outwash has little effect on the vertical leakage rate.

\section{Transient Calibration to the Irrigation Season of 1988}

The values for model-input parameters and the design of the model appeared reasonable when simulating water-level declines during the 1986 irrigation season. Another test of the model would demonstrate the model's ability to (1) simulate water-level declines in another year besides 1986 , and (2) simulate temporary depletion of water from the carbonate bedrock aquifer. The aquifer can become temporarily depleted by lowering water levels below the surface of the bedrock, thus extending the normal period of water-level recovery. An appropriate test of these conditions was accomplished by use of irrigation pumpage from 1988, a year when pumpage increased by about two-thirds over that for 1986 .

Initial water levels for the second calibration were calculated by simulating steady-state conditions in late April 1988. Using a recharge rate of $11 \mathrm{in} / \mathrm{yr}$, the steady-state simulation provided a set of water levels similar to the measured levels in April. The simulated, steady-state water levels were then used as initial water levels for the second calibration.

The second calibration period began on May 1, 1988, and lasted 5 months. Each month corresponded to individual stress periods. Each stress period was divided into six time steps, and each time step was equal to 1.5 times the length of the previous step.
Hydrographs of simulated and measured water levels are shown in figure 13. The hydrographs are for the same observation wells as shown in figure 10 . Generally, the simulated hydrographs for the second transient calibration demonstrate the same pattern as the measured hydrographs and follow the measured trend of water levels as they did in the first transient calibration. The difference between simulated and measured water levels is slightly greater than that observed after the first transient calibration. A greater difference is to be expected because pumpage for the second transient calibration is two-thirds greater than that for the first transient calibration. Therefore, error in the model input is amplified somewhat when compared to the first transient calibration. The mean absolute error in simulated water levels for 22 sites in the outwash aquifer was $4 \mathrm{ft}$; for 22 sites in the carbonate bedrock aquifer, it was $7 \mathrm{ft}$. On the average, the simulated water levels were $1 \mathrm{ft}$ below measured values in the outwash aquifer and $0.9 \mathrm{ft}$ above measured water levels in the carbonate bedrock aquifer.

The second calibration provided an opportunity not only to test the model's simulation capability but also to improve on three types of model input in small areas. Changes to input parameters were made in the areal vertical hydraulic conductivity of the confining unit and locally in bedrock-surface altitudes and clay thickness. During the first calibration, a single value for vertical hydraulic conductivity of the clay confining unit was assigned to all clay layers in all areas. An areal trend in the water-level hydrographs was observed during the second calibration that was not addressed during the first calibration. Drawdowns for simulated water levels near the western boundary generally were less than measured water levels. The agreement between simulated and measured water levels was improved by decreasing vertical hydraulic conductivity of the clay confining unit in the areas delineated by figure 14.

Also, errors in bedrock-surface altitude at four nodes became evident during the second calibration. Simulated water-level declines at a few wells in the center of the modeled area flattened at altitudes that were several feet different than the altitudes of the measured water levels. The 

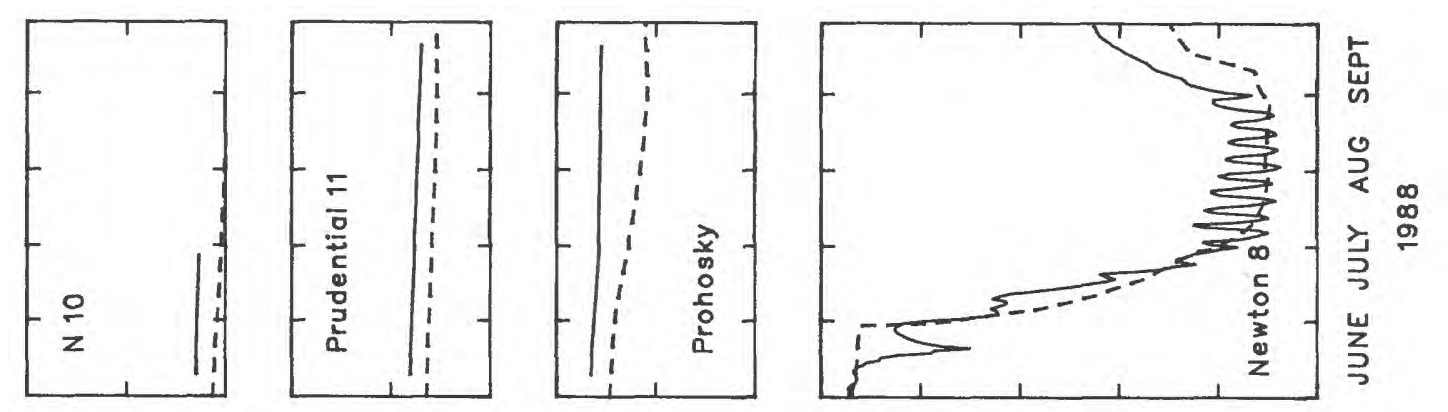

$\infty$
0
0
0
0
0
0
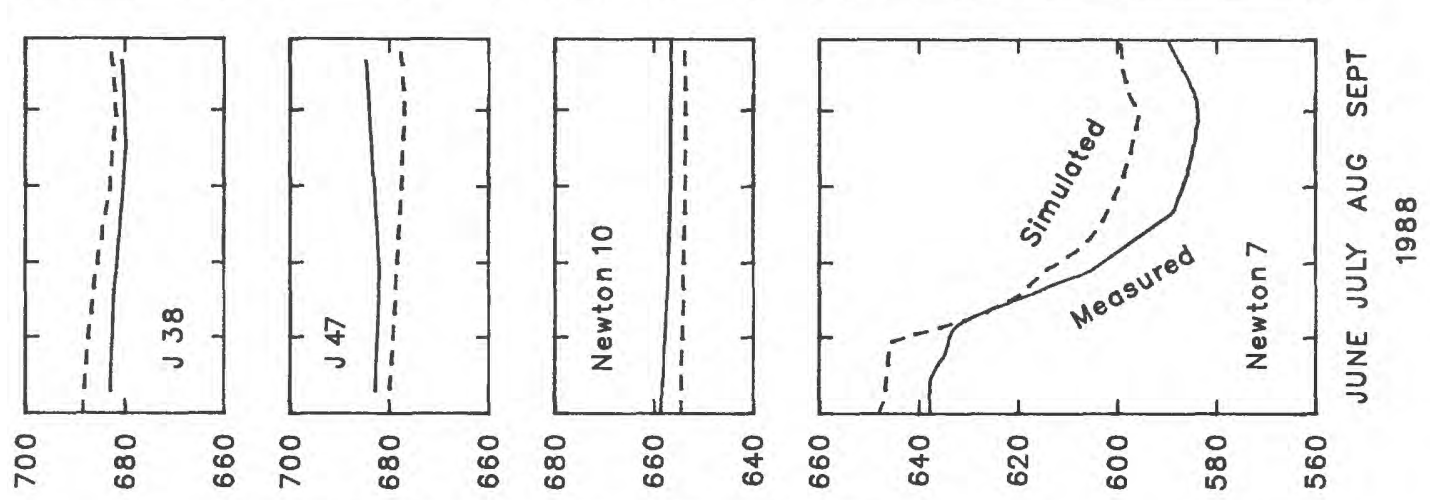

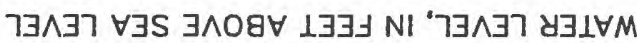
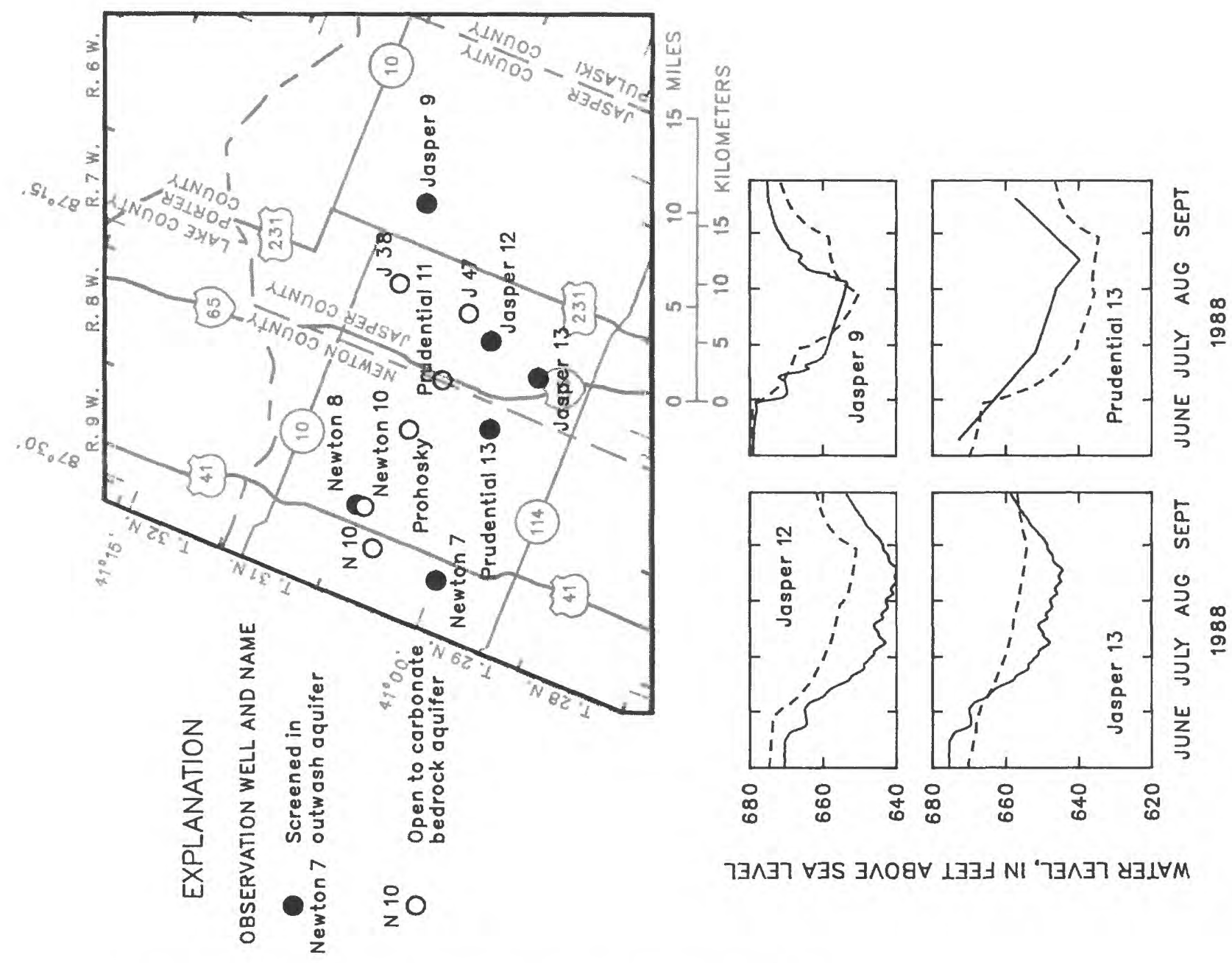

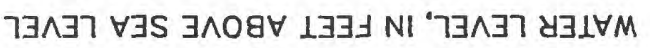

즐

(5)

일

$\stackrel{0}{+}$

는

망

כ

일

文

옹

อ

임

E

듬

号

ए।

ํㅡㄴ 


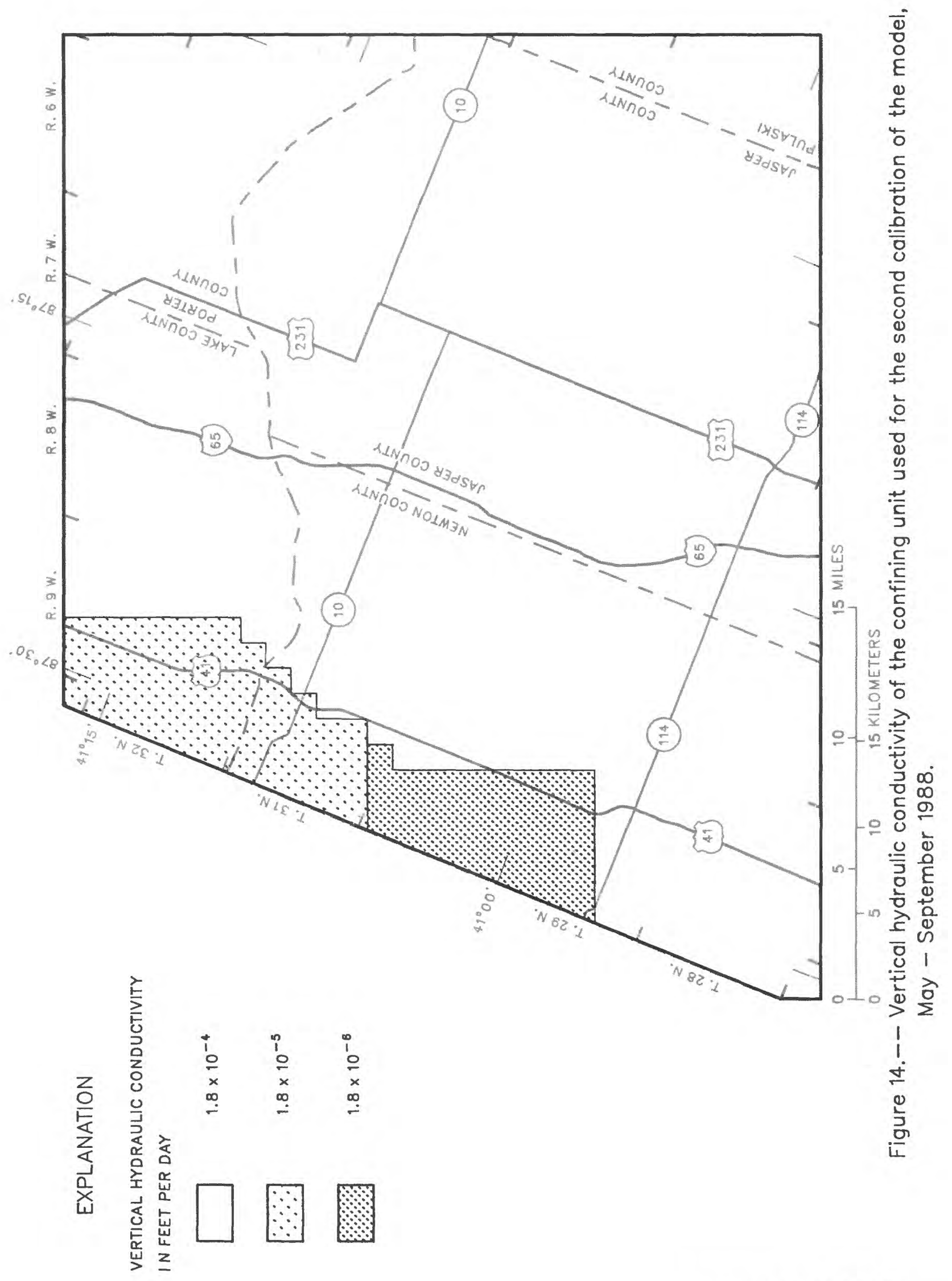


flattening of both the simulated and measured hydrographs indicates that the water level had declined to the bedrock aquifer. At that point, the confined bedrock aquifer became unconfined (see hydrograph for Newton 8 in fig. 13). The change from confined to unconfined (water-table) conditions is characterized by a large increase in the yield from storage per foot of hydraulic-head decline. The flat part of the hydrograph is an indication of the bedrock surface, which was incorrectly estimated at two nodes. The bedrocksurface altitudes were corrected within the probable range indicated by well logs, and the flat part of the simulated hydrographs corresponded more closely to the measured hydrographs.

Lastly, the estimate of clay thickness between the outwash aquifer and the bedrock aquifer was improved at three nodes in the middle of the modeled area. Measured drawdowns indicated that the vertical hydraulic conductivity of the clay confining unit near the wells must be similar to that of sand and gravel. In other words, the clay confining unit appeared to be nearly absent in small areas (less than $1 \mathrm{mi}^{2}$ ). When clay thickness was decreased to about $1 \mathrm{ft}$ at the nodes, drawdown for the simulated hydrographs decreased by several feet and more closely matched the measured hydrographs. The new estimate for clay thickness at the Prohosky observation well (fig. 13), for example, caused a 25 - $\mathrm{ft}$ change in simulated water levels for the bedrock aquifer. This large waterlevel change demonstrates the importance of correctly determining clay thickness in areas where irrigation is concentrated. The substantial effect that the clay confining unit had on drawdown in such areas suggests that the model can be useful where measured water levels are available, but simulations could be in error by several feet where measured water levels are not available and where clay thickness is variable and not adequately described by well logs.

Simulated flow for each component of the ground-water flow system before most irrigation pumpage began in June 1988 is given in table 6. The same components of flow for a period of maximum drawdowns in August 1988 is given in table 7. About 35 percent less ground water flowed in the ground-water system in June and 20 percent less in August 1988, compared to flows in the same months in 1986 . Withdrawals were not the reason for the decrease in flow rates between the 2 years. For example, withdrawals increased by only $12 \mathrm{ft}^{3} / \mathrm{s}$ in June 1988 compared to June 1986, while the total flow rate decreased by $176 \mathrm{ft}^{3} / \mathrm{s}$. The flow rate through the ground-water system decreased because recharge was appreciably less in 1988 than in 1986. This decrease is reflected in the lower water levels used for initial conditions in May 1988. Even in the dry year of 1988 with increased irrigation, withdrawals in August were still only 28 percent of total flow through the system. Even though flow through the system decreased, the change in flow at the boundary from 1986 to 1988 is only about $5 \mathrm{ft}^{3} / \mathrm{s}$. Boundary fluxes remain about the same regardless of conditions inside the boundary. Similar boundary fluxes imply the effect from the boundaries remains about the same, regardless of inside stresses.

Table 6. Water budget determined by the second calibration for June 1988

\begin{tabular}{|c|c|c|c|}
\hline \multicolumn{2}{|c|}{$\begin{array}{c}\text { Inflow } \\
\text { (cubic feet per second) }\end{array}$} & \multicolumn{2}{|c|}{$\begin{array}{l}\text { Outflow } \\
\text { (cubic feet per second) }\end{array}$} \\
\hline Precipitation & 0 & Ground-water pumpage & 80 \\
\hline Storage & 257 & Storage & 3 \\
\hline $\begin{array}{l}\text { Ground-water } \\
\text { recharge from } \\
\text { streams }\end{array}$ & 6 & $\begin{array}{l}\text { Ground-water } \\
\text { discharge to } \\
\text { streams }\end{array}$ & 242 \\
\hline Boundary inflow & 70 & Boundary outflow & 9 \\
\hline Total inflow & 333 & Total outflow & 334 \\
\hline
\end{tabular}

Table 7. Water budget determined by the second calibration for August 1988

\begin{tabular}{|c|c|c|c|}
\hline \multicolumn{2}{|c|}{$\begin{array}{c}\text { Inflow } \\
\text { (cubic feet per second) }\end{array}$} & \multicolumn{2}{|l|}{$\begin{array}{c}\text { Outflow } \\
\text { (cubic feet per second) }\end{array}$} \\
\hline Precipitation & 0 & Ground-water pumpage & 78 \\
\hline Storage & 197 & Storage & 3 \\
\hline $\begin{array}{l}\text { Ground-water } \\
\text { recharge from } \\
\text { streams }\end{array}$ & 7 & $\begin{array}{l}\text { Ground-water } \\
\text { discharge to } \\
\text { streams }\end{array}$ & 187 \\
\hline Boundary inflow & 73 & Boundary outflow & 10 \\
\hline Total inflow & 277 & Total outflow & 278 \\
\hline
\end{tabular}


Because a few of the input data were changed, however, the 1986 calibration data set was simulated again with the model-input changes incorporated. The resulting hydrographs are shown in figure 15 . Some of the hydrographs in figure 13 were shifted vertically because the resimulation of 1986 data began at a somewhat different initial water level. The only difference in water-level trends appears in the hydrograph for Newton 7. Simulated drawdown for this observation well is greater in figure 15 than in figure 12, which reflects the reduced vertical hydraulic conductivity of the confining unit used for the resimulation of 1986 drawdowns. The reduced vertical hydraulic conductivity used in the second calibration caused a similar amount of water-level drawdown in the simulated hydrograph as that in the measured hydrograph (fig. 15). The effect of irrigation pumpage on water-level contours of the bedrock aquifer after the changes to model input are shown in figure 16. Although flow is still from the morainal areas to the river, local cones of depression are formed around some pumping centers. The water budget for resimulation of the 1986 data is similar to the one given in table 4 . The maximum percentage change between the two budgets for the transient calibration and the resimulation of the calibration was a 0.6-percent change in total flow through the ground-water system for June 1986. Therefore, model response to conditions in 1986 was changed little because of the changes to model input.

\section{Sensitivity Analysis and Evaluation}

The purpose of the sensitivity analysis was to determine which model parameters most affect simulated water levels in the bedrock aquifer. During transient calibration, parameters that affected water levels in the outwash aquifer did not appear to affect water levels in the bedrock aquifer. If certain parameters substantially affect simulated water levels, then these parameters require accurate values for the model results to be considered reliable.

During transient calibration, vertical hydraulic conductivity of the confining unit and transmissivity of the carbonate bedrock aquifer appeared to affect simulated water levels the most. Four model simulations were done after transient calibration to quantify the sensitivity of simulated water levels to parameter values by halving, and then doubling, the calibrated values of vertical hydraulic conductivity and transmissivity at each node. One parameter was changed while the other was held constant during each of four simulations. The mean absolute errors of simulated water levels caused by changes in calibrated values of the two parameters are compared in table 8.

The greatest overall mean absolute error $(14.9 \mathrm{ft}$ ) resulted when values of vertical hydraulic conductivity of the confining unit were doubled. Based on the four sensitivity simulations, the parameter most affecting water levels was vertical hydraulic conductivity of the confining unit (table 8). The calibrated value used for vertical hydraulic conductivity in this study probably is reliable because of the large number of water-level data that were available for the calibration.

Table 8. Results of changes in vertical hydraulic conductivity and transmissivity on the mean absolute errors of simulated water levels

\begin{tabular}{lc}
\hline \multicolumn{1}{c}{ Parameter value } & $\begin{array}{c}\text { Mean absolute error } \\
\text { (feet) }\end{array}$ \\
\hline 0.5 x calibrated vertical hydraulic conductivity of confining unit & 10.3 \\
$2.0 \times$ calibrated vertical hydraulic conductivity of confining unit & 14.9 \\
$0.5 \times$ calibrated transmissivity of carbonate bedrock aquifer & 6.39 \\
2.0 x calibrated transmissivity of carbonate bedrock aquifer & 5.63 \\
Parameter values unchanged from calibration & 5.01 \\
\hline
\end{tabular}



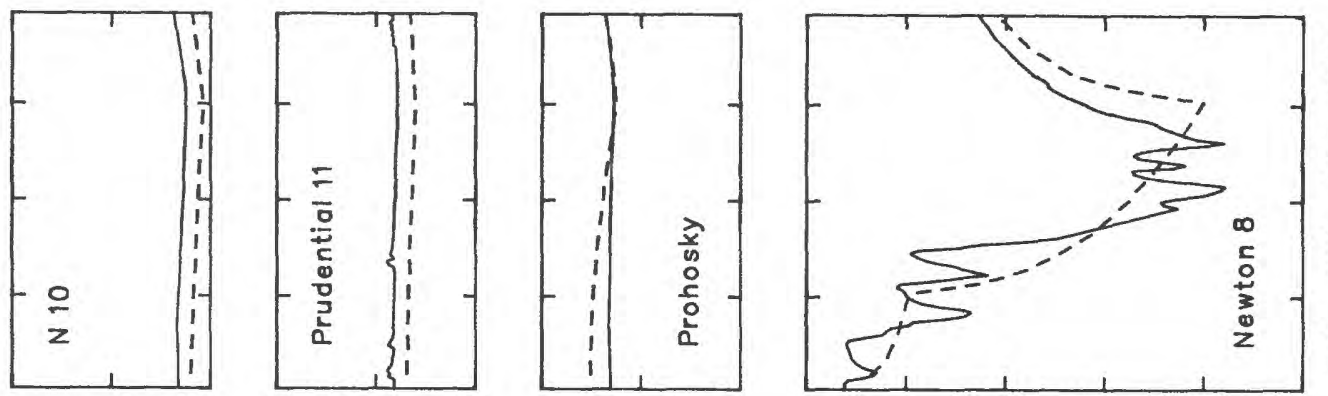

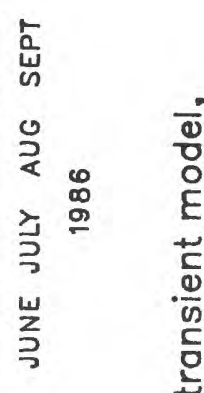
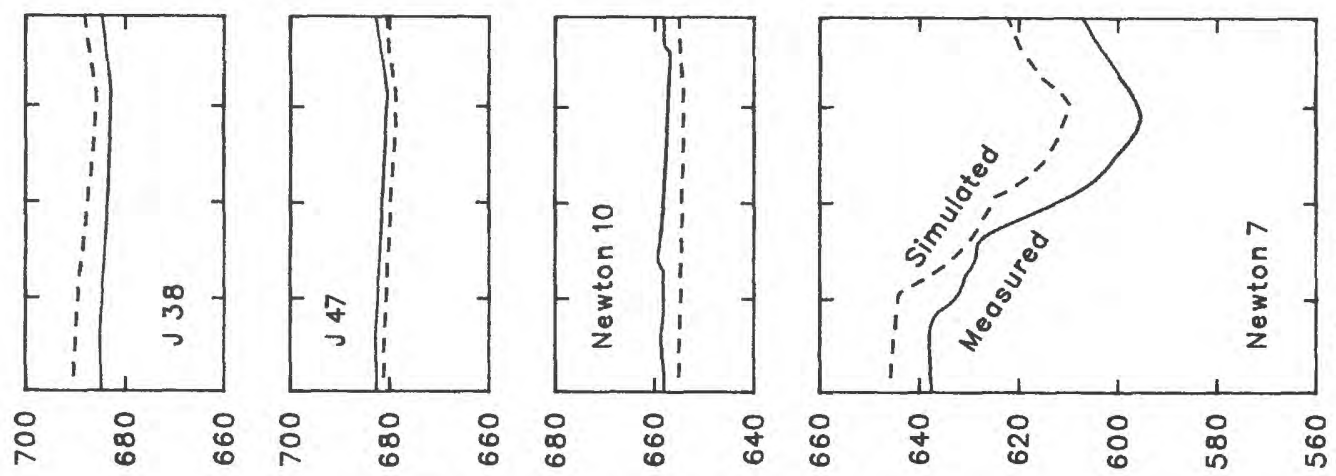

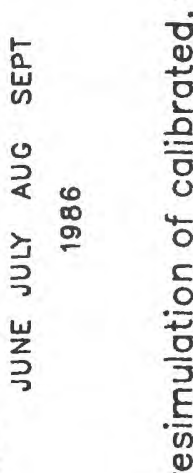
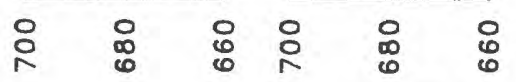

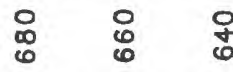

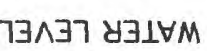
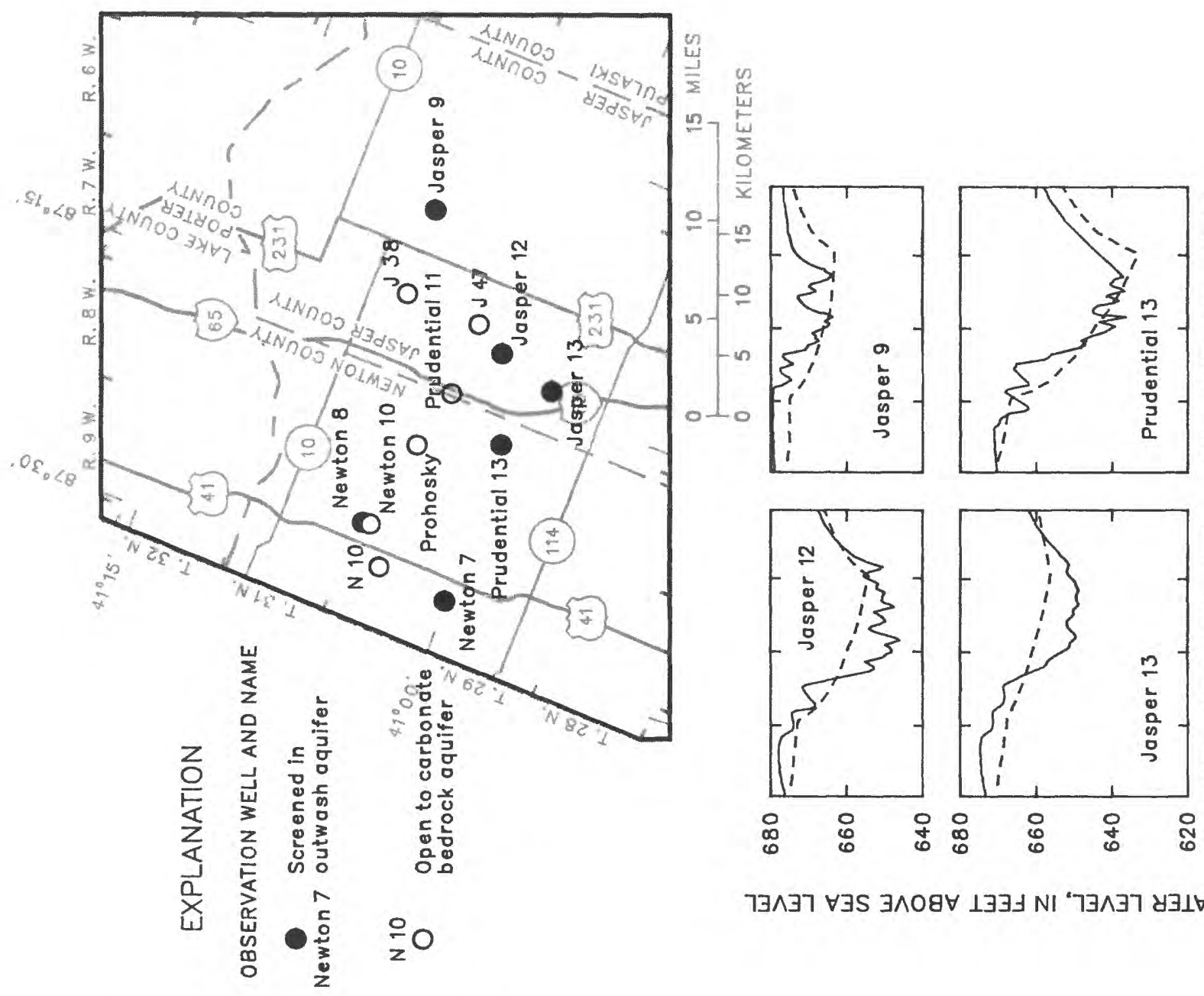

点

¿

D

อ

$\frac{0}{0}$

อ

㐫

3

¿ழ

รั

o.

$\stackrel{2}{\circ}$

$\varepsilon$ ह

응

ర్

品

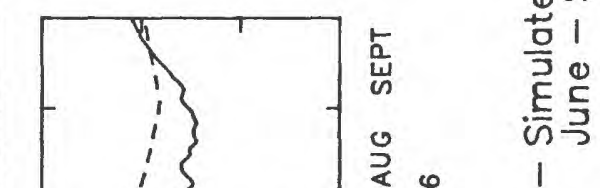

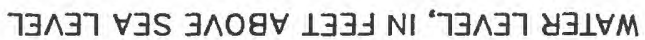




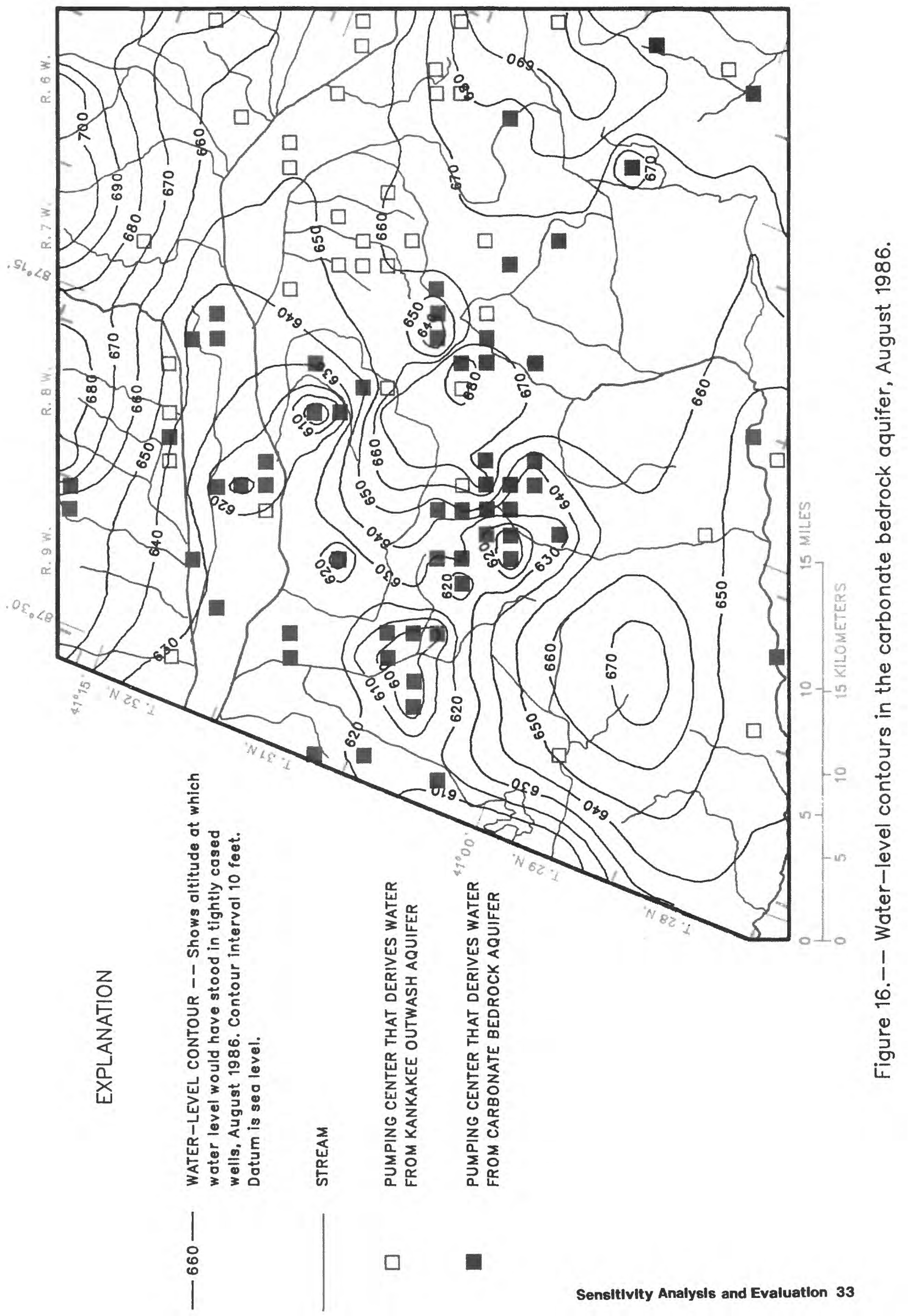




\section{Limitations and Evaluation of the Model}

The ability of models to simulate actual ground-water conditions is limited by (1) the modeler's concept about which basic processes are important to ground-water flow and (2) the availability and quality of data on the extent and hydraulic characteristics of aquifers and confining units. Limitations of this model will be discussed on the basis of these factors. Finally, an overall evaluation of the model will be presented.

Previous ground-water models of county-size areas in the glaciated part of Indiana successfully simulated ground-water flow by conceptualizing that recharge to the carbonate bedrock aquifer is derived mostly from vertical flow through the till overlying the bedrock (Lapham,1981; Arihood, 1982). In such a system, vertical hydraulic conductivity of the till becomes an important parameter, and it was determined to be important in this system as well. The parameter that was most effective in matching simulated water levels to measured levels throughout the modeled area is vertical hydraulic conductivity of the confining unit.

Because vertical hydraulic conductivity of the confining unit is critical to calibration of the model, the model should be most reliable where most data on vertical conductivity is available for calibration. Although direct measurement of vertical conductivity was not done, indirect measurement was accomplished by adjusting vertical conductivity until simulated water levels were close to the measured levels in the bedrock. Because several water levels are available in the central part of the model, the model should provide reliable estimates of ground-water conditions in that area.

As a measure of model reliability for the entire area, the mean absolute error for water levels in the bedrock was divided by the maximum fluctuation of water levels observed during an irrigation season. This quotient multiplied by 100 is defined as the percent error in estimated water levels. On this basis, simulated water levels average within 6 and 8 percent of the measured levels during the 1986 and 1988 calibration periods, respectively.

The lateral boundaries of the ground-water flow system were simulated by constant heads. In the section titled "Transient Calibration to the Irrigation Season of 1986," justification for constant-head boundaries was based on the observation that boundary inflows change little from the simulation of 1986 to that of 1988. Also, boundary inflows are likely to discharge to nearby streams and not to wells in the center of the model. These wells are likely to derive water by diverting flows from streams near the wells and by releasing water from storage. If pumping wells, however, are placed near one of the constant-head boundaries, then drawdowns would be underestimated by the model because the constant-head nodes will tend to supply more water than actually is available. The appropriate area of the model to simulate moderate and large withdrawals is its central part.

The model can be evaluated by how well it simulates actual fluxes to and water levels in the bedrock. Simulated fluxes and water levels can be adjusted to near the actual values during calibration by adjusting the vertical hydraulic conductivity of the confining unit. The value of vertical conductivity determined during the first calibration (1986 irrigation season) was tested by the second calibration (1988 irrigation season). The withdrawals of 1988 were the largest recorded, and future withdrawals probably will not be larger because of limitations imposed by water-rights law in Indiana. Therefore, the model has been tested by simulating moderate (1986) and large (1988) withdrawals from bedrock, and simulated water levels have averaged within 6 to 8 percent of measured levels.

\section{SUMMARY}

Water for irrigation in parts of Newton and Jasper Counties and adjacent areas of northwestern Indiana is pumped mostly from the carbonate bedrock aquifer that underlies glacial drift. 
A concern related to pumping has been the lowering of water levels in the carbonate bedrock aquifer until the aquifer becomes dewatered and depleted.

As part of managing the ground-water resource, the Indiana Department of Natural Resources has supported the development and testing of a three-dimensional computer model of the ground-water-flow system.

Two major aquifers and a confining unit constitute the ground-water system in parts of Newton and Jasper Counties and adjacent areas of northwestern Indiana. The surficial unconfined aquifer, called the outwash aquifer, consists of fine to coarse sand and fine to medium gravel. Saturated thickness averages about $30 \mathrm{ft}$. The outwash aquifer is the principal source of ground water for stock and domestic supply and a major source for irrigation water in the northeastern part of the study area. Large-capacity wells completed in the aquifer generally yield from 100 to $200 \mathrm{gal} / \mathrm{min}$. Estimated values of horizontal hydraulic conductivity and storage coefficient are $350 \mathrm{ft} / \mathrm{d}$ and 0.07 , respectively. The confining unit is generally continuous, ranges in thickness from 0 to $125 \mathrm{ft}$, and is composed predominantly of till and lacustrine silt and clay. The vertical hydraulic conductivity of the confining unit is estimated to range from $1.8 \times 10^{-4}$ to $1.8 \times 10^{-6} \mathrm{ft} / \mathrm{d}$. The carbonate bedrock aquifer underlies the confining unit and is composed predominantly of Silurian and Devonian dolomitic limestone and dolomite. The bedrock aquifer supplies most of the ground water for irrigation. Wells in the bedrock aquifer yield from 10 to $2,200 \mathrm{gal} / \mathrm{min}$, mostly from fractures. Regional transmissivity for the bedrock aquifer ranges from 1,000 to $5,000 \mathrm{ft}^{2} / \mathrm{d}$, and the median calculated transmissivity is about $2,000 \mathrm{ft}^{2} / \mathrm{d}$.

Irrigation pumpage causes seasonal waterlevel fluctuations in the bedrock aquifer. Recharge to the outwash aquifer is commonly from 12 to $14 \mathrm{in} / \mathrm{yr}$, and recharge to the confining unit is about $1 \mathrm{in} / \mathrm{yr}$. Total irrigation pumpage from the two aquifers during the months of June, July, and
August 1986 was $10.0,40.5$, and $40.6 \mathrm{Mgal} / \mathrm{d}$, respectively. Ground-water levels were highest in the aquifers in the spring and lowest during July and August. Seasonal fluctuations in water levels for the bedrock aquifer were due mainly to the low storage coefficient of the aquifer and to largescale pumpage during the summer. Water-level fluctuations in the bedrock aquifer ranged from about 5 to $80 \mathrm{ft}$.

A nine-layer digital model was used to simulate flow in the ground-water system. The model incorporated geologic information and estimates of transmissivity and horizontal hydraulic conductivity from driller's logs, estimates of recharge from streamflow data, and historical withdrawal data. The model was calibrated by use of historical water-level records and gain/loss data for streams during base-flow conditions collected during August 1986. The model then was recalibrated with data from 1988 . The mean absolute error for simulated water levels in the bedrock aquifer ranged from 5 to $7 \mathrm{ft}$ for two periods of irrigation. The most important component of the flow system affecting waterlevel drawdowns in the carbonate bedrock aquifer is the clay confining unit, which controls the rate of leakage to the bedrock aquifer. The model yields the most accurate simulations when data for confining-unit thickness and bedrock water levels are available. The model will underpredict drawdown if proposed pumping sites are located too close to the constant-head model boundaries. The appropriate area for simulations of withdrawals is the central part of the modeled area. Model results indicate that most ground water in the study area is derived locally from precipitation that percolates to the bedrock aquifer, rather than from ground water that enters the study area across area boundaries. Recharge from precipitation varies from year to year, in June 1988, simulated flow through the ground-water system was 35 percent less than in June 1986. Pumping does not significantly affect total flow in the system. Even in the dry year of 1988 with increased irrigation, withdrawal in August was still only 28 percent of total flow through the system. 


\section{REFERENCES}

Arihood, L.D., 1982, Ground-water resources of the White River basin, Hamilton and Tipton Counties, Indiana: U.S. Geological Survey Water-Resources Investigations Report 82-48, 69 p.

Basch, M.E. and Funkhouser, R.V., 1985, Irrigation impacts on ground-water levels in Jasper and Newton Counties, Indiana, 1981-1984: Indiana Department of Natural Resources, Division of Water, Water Resource Assessment 85-1, 109 p.

Bergeron, M.P., 1981, Effect of irrigation pumping on the ground-water system in Newton and Jasper Counties, Indiana: U.S. Geological Survey WaterResources Investigations Report 81-38, 73 p.

Brown, R.H., 1963, Estimating the transmissibility of an artesian aquifer from the specific-capacity of a well, in Bentall, Ray, compiler, Methods of determining permeability, transmissibility, and drawdown: U.S. Geological Survey Water-Supply Paper 1536-I, p. I336-I338.

Governor's Water Resources Study Commission, State of Indiana, 1980, The Indiana water resource availability, uses, and needs: Indiana Department of Natural Resources, 508 p.

Kemp, Kenneth, 1970, Predictions of agricultural irrigation for Indiana and irrigation potentials of selected Indiana soil series: Indiana Department of Natural Resources, $238 \mathrm{p}$.

Kemp, Kenneth, Russell, J.O., Mannering, J.V., Wiersma, Dan, and Sisson, D.R., 1967, Indiana agricultural irrigation in 1967: Indiana Department of Natural Resources, State Water Plan Section, $27 \mathrm{p}$.

Lapham, W.W., 1981, Ground-water resources of the White River basin, Madison County, Indiana: U.S. Geological Survey Water-Resources Investigation Report 81-35, 112 p.

McDonald, M.G., and Harbaugh, A.W., 1984, A modular three-dimensional finite-difference ground-water flow model: U.S. Geological Survey Open-File Report 83-875, 528 p.

National Oceanic and Atmospheric Administration, 1977, Climatological data, Indiana: National Oceanic and Atmospheric Administration Environmental Data Service, Annual Summary 1977 , v. 82, no.13, p. 4 and 6.
1985, Climatological data, Indiana: National Oceanic and Atmospheric Administration Environmental Data Service, Annual Summary 1985, v. 90, no. $13,32 \mathrm{p}$.

Rosenshein, J.S., and Hunn, J.D., 1964a, Ground-water resources of northwestern Indiana, preliminary report--Jasper County: Indiana Department of Conservation, Division of Water Resources Bulletin $25,83 \mathrm{p}$.

1964b, Ground-water resources of northwestern Indiana, preliminary report--Newton County: Indiana Department of Conservation, Division of Water Resources Bulletin 26,69 p.

1968, Geohydrology and ground-water potential in Lake County, Indiana: Indiana Department of Natural Resources, Division of Water Bulletin 31, $36 \mathrm{p}$.

Schneider, A.F., 1966, Physiography, in Lindsey, A.A., ed., Natural features of Indiana: Indiana Academy of Science, p. 40-56.

Schneider, A.F., and Keller, S.J., 1970, Geologic map of the $1 \times 2$ Chicago quadrangle showing bedrock and unconsolidated deposits: Indiana Geological Survey Regional Geologic Map No. 4, scale 1:250,000, 1 sheet.

State of Indiana, U.S. Department of Agriculture, and U.S. Department of the Interior, 1976, Report on the water and related land resources, Kankakee River basin: Lincoln, Nebr., U.S. Department of Agriculture, Soil Conservation Service, variable pagination.

Uhl, John, and Kingsbury, Theodore, 1957, Irrigation in Indiana using ground-water resources: Indiana Department of Conservation, Division of Water Resources, 24 p.

U.S. Department of Commerce, Bureau of the Census, 1986, Current population report, local population estimate: Series P26, 130 p.

Watkins, F.A., Jr., and Rosenshein, J.S., 1963, Groundwater geology and hydrology of the Bunker Hill Air Force Base and vicinity, Peru, Indiana: U.S. Geological Survey Water-Supply Paper 1619-B, 32 p.

Wayne, W.J., Johnson, G.H., and Keller, S.J., 1966, Geologic map of the 1 x 2 Danville Quadrangle, Indiana and Illinois: Indiana Geological Survey Regional Geologic Map No.2, scale 1:250,000, 1 sheet. 


\section{GLOSSARY}

Ancestral. Previously existing.

Anisotropy. Having some physical property that varies with direction.

Aquifer. A water-bearing zone below the surface of the Earth that will yield water in a usable quantity to a well or spring.

Aquifer geometry. The description of the physical dimensions of an aquifer.

Axis. A straight line, real or imaginary, following the trend of a large formation or landform.

Calibration. The trial-and-error process of adjusting model-input data until model output is similar to measured conditions. For example, in this report, calibration may refer to the adjustment of bedrock transmissivity values (a model input) until simulated ground-water levels (model output) are similar to measured water levels.

Carbonate bedrock. A sedimentary rock consisting chiefly of carbonate $\left(\mathrm{CO}_{3}{ }^{-2}\right)$ minerals, such as limestone $\left(\mathrm{CaCO}_{3}\right)$ and dolomite $\left[\mathrm{CaMg}\left(\mathrm{CO}_{3}\right)_{2}\right]$.

Confined. Used to describe an aquifer in which ground-water is isolated from the atmosphere by low-permeability formations.

Confining unit. A slightly permeable formation that stratigraphically isolates one or more aquifers.

Consolidated material. Earth material that has become firm and coherent rock.

Constant-head boundary. A model boundary condition where the water level is constant over time.

Dewater. The removal of water from an unconfined aquifer until water levels cannot recover after seasonal recharge.

Dolomite. A carbonate sedimentary rock of which more than 50 percent by weight consists of magnesium carbonate $\left[\mathrm{CaMg}\left(\mathrm{CO}_{3}\right)_{2}\right]$.

Drawdown. The lowering of the water level in a well as a result of withdrawals.

Drift. In this report, any rock material, such as boulders, till, gravel, sand, or clay, transported by a glacier and deposited by or from the ice or by or in water derived from the melting of the ice.

End moraine. Moraine marking the terminal position of a glacier.
Evapotranspiration. Loss of water from a land area by evaporation from water surfaces and moist soil and by plant transpiration.

Flux. The flow of a volume of water per unit of time across a unit surface.

Fracture. Breaks in rocks caused by geologic processes such as folding, faulting, and weathering.

Free-surface boundary. A model boundary condition that describes the upper surface of a layer of fluid where the pressure on it is equal to the external atmospheric pressure; the water table.

Gain/loss study. Measurements of streamflow are made at several points along a stream to determine whether the stream is gaining water from or losing water to the ground-water system.

Geohydrology. The description of the geologic and hydrologic characteristics of a ground-water system.

Glacial drift. Drift transported by glaciers. See "Drift."

Ground moraine. The material deposited by a glacier on the ground surface over which the glacier has moved.

Ground-water discharge. The outflow of water from the ground-water system.

Head. Height of the free surface of a body of water above a given subsurface point.

Head-dependent flux boundary. A model boundary condition at which flux changes depending on the value of water level outside the boundary.

Heterogeneous. Consisting of dissimilar constituents that vary in position.

Hydraulic characteristics. Constants that are used to define the movement and storage of water in a ground-water system.

Hydraulic conductivity. The rate at which water flows through a unit cross-sectional area of aquifer under a unit hydraulic gradient at the existing viscosity of water.

Hydraulic gradient. The rate of change of hydraulic head per unit of distance of flow at a given point and in a given direction.

Ice-contact stratified deposit. Stratified drift deposited in contact with melting glacier ice (see "Stratified drift").

Lacustrine. Pertaining to, produced by, or formed in a lake. 


\section{Glossary-Continued}

Limestone. A sedimentary rock consisting chiefly of calcium carbonate $\left(\mathrm{CaCO}_{3}\right)$.

Mean absolute error. The sum of the absolute differences between simulated and measured water levels divided by the number of measurements.

Median. The middle number in a set of numbers ranked by their magnitude.

Moraine. An accumulation of unsorted, unstratified drift deposited chiefly by the direct action of glacial ice.

No-flow boundary. A model boundary condition across which no ground water flows.

Outwash. Drift deposited beyond the moving glacial ice by meltwater streams.

Outwash plain. A broad, gently sloping sheet of material washed out by melting glacial ice and deposited in front of or beyond a glacier.

Permeability. The conductive property of the porous medium alone. Hydraulic conductivity is the conductive property of a specific fluid flowing through a porous medium.

Piezometer. A well measuring the water level in a slightly permeable formation.

Recharge. The process or amount of water entering the saturated zone in the ground-water system.

Sandstone. A rock composed of sand-sized quartz grains cemented together.

Saturated thickness. Amount of water-bearing material filled with water under pressure greater than atmospheric.

Sensitivity analysis. A series of model simulations used to determine which model parameters most affect simulated water levels.

Shale. 'A laminated consolidated sediment composed mostly of clay particles.
Siltstone. A fine-grained consolidated sediment composed mostly of silt particles.

Specific yield. The volume of water that an unconfined aquifer releases from storage unit surface area of aquifer per unit decline in the water table.

Specified-head boundary. Similar to a constant-head boundary in that the model boundary condition can supply an unlimited quantity of water, but the water level can change with time.

Steady-state. A condition where flow velocity at any point in the flow field is constant over time in magnitude and direction.

Storage coefficient. The volume of water that an aquifer releases from storage per unit surface area of the aquifer per unit decline in water level.

Stratified drift. Distinct layers of drift deposited in association with a glacier and containing material sorted uniformly on the basis of some physical property.

Streamflow duration. Referring to a percentage of the time that a specific streamflow is equaled or exceeded at a point in a stream.

Surficial. Pertaining to or occurring on the Earth's surface.

Till. Unsorted, unstratified drift carried or deposited by a glacier.

Till plain. An extensive area, with a flat to undulating surface, underlain by till with subordinate end moraines.

Transmissivity. The rate at which water at the prevailing viscosity is transmitted through a unit width of an aquifer under a unit hydraulic gradient, reported in $\mathrm{ft}^{2} / \mathrm{d}$.

Transient. A condition where flow velocity at any point in the flow field varies in magnitude and in time.

Unconfined. Describes an aquifer in which the water table forms the upper aquifer boundary.

Unconsolidated deposits. Earth material that is loosely packed and whose particles are not cemented together. 